\title{
The Emergence of New Psychoactive Substance (NPS)
}

\section{Benzodiazepines: A Review}

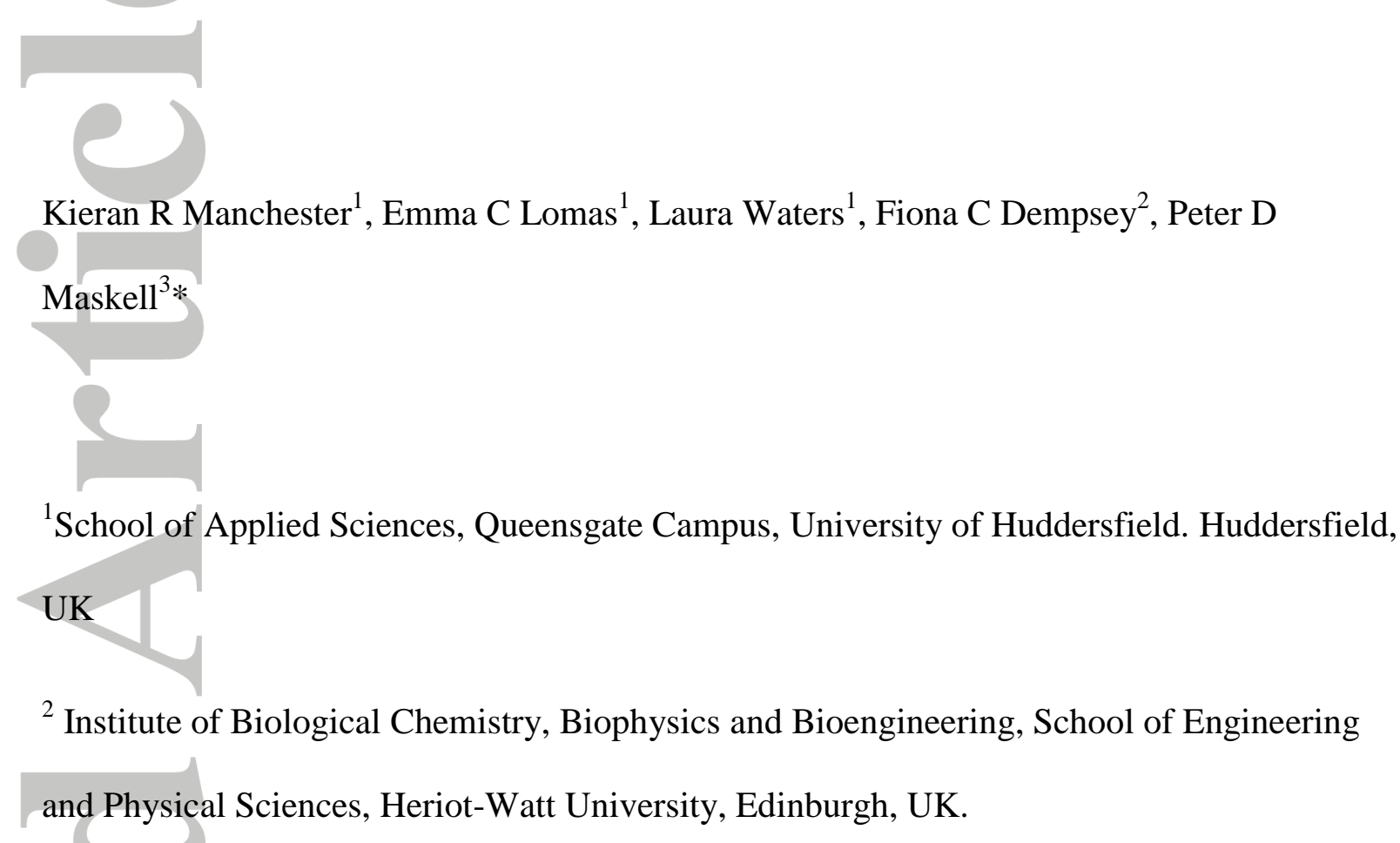

${ }^{3}$ School of Science, Engineering and Technology, Abertay University, Dundee, UK.

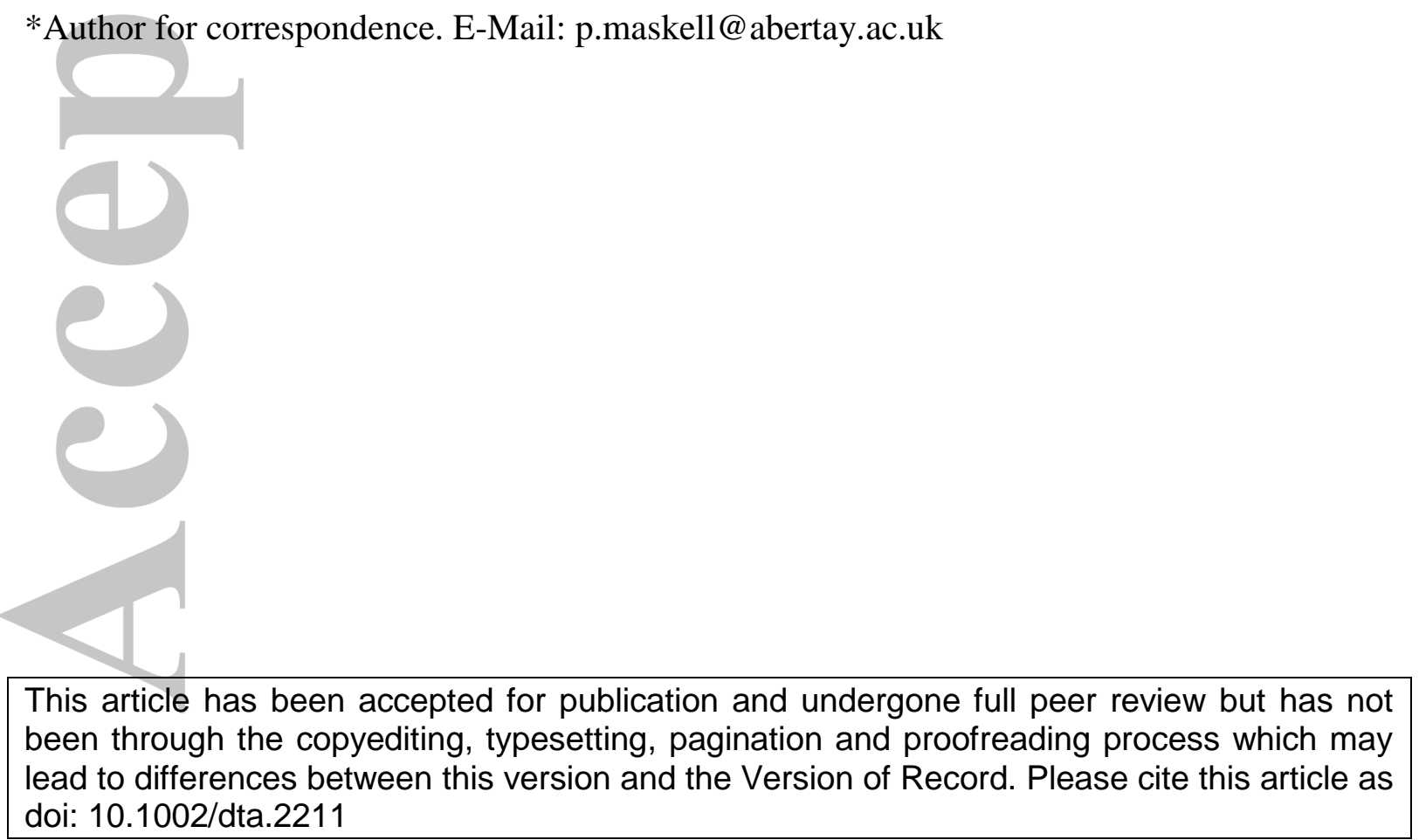

This article is protected by copyright. All rights reserved. 


\section{Abstract}

The market for new psychoactive substances has increased markedly in recent years and there is now a steady stream of compounds appearing every year. Benzodiazepines consist of only a fraction of the total number of these compounds but their use and misuse has rapidly increased. Some of these benzodiazepines have only been patented, some of them have not been previously synthesised and the majority have never undergone clinical trials or tests. Despite their structural and chemical similarity, large differences exist between the benzodiazepines in their pharmacokinetic parameters and metabolic pathways and so they are not easily comparable. As benzodiazepines have been clinically used since the 1960s many analytical methods exist to quantify them in a variety of biological matrices and it is expected that these methods would also be suitable for the detection of benzodiazepines that are new psychoactive substances. Illicitly obtained benzodiazepines have been found to contain a wide range of compounds such as opiates which presents a problem since the use of them in conjunction with each other can lead to respiratory depression and death. The aim of this review is to collate the available information on these benzodiazepines and to provide a starting point for the further investigation of their pharmacokinetics which is clearly required.

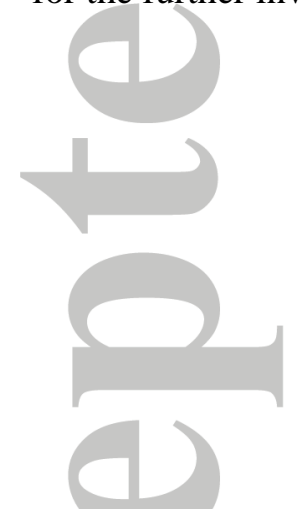

Keywords: Benzodiazepine, NPS, drug abuse, legal highs 


\section{The use and misuse of benzodiazepines}

The use and misuse of new psychoactive substances (or "legal highs") has increased significantly around the world in the past 10 years [1] and has to date showed no signs of slowing. In Europe alone the total number of new compounds reported by the European Monitoring Centre for Drugs and Drug Addiction (EMCDDA) has risen rapidly since 2007 with 101 new psychoactive substances reported to the EMCDDA in 2014 [2] and 98 in 2015 [3]. The majority of these compounds have been synthetic cannabinoids, cathinones and phenylethylamines [2]. One group of these compounds, the benzodiazepines, have received limited attention but their use has increased significantly in the past few years. The abuse potential for benzodiazepines was recognised early in their use and led to 33 benzodiazepines being placed under control by the UN Convention on Psychotropic Substances 1971 [4]. Benzodiazepines are one of the most prescribed groups of drugs around the world with the limited available data suggesting that $5.6 \%$ of Americans filled a benzodiazepine prescription in 2013 [5]. In England over 5 million doses of diazepam alone were dispensed in 2014, whilst the total number of prescriptions issued for benzodiazepines stood at more than 10.4 million, indicating their widespread use [6] Benzodiazepines are also linked to a significant number of deaths, both via abuse as a drug in their own right and also as part of a deliberate poly pharmacy regime [7]. They are commonly implicated in cases of opioid overdoses, where benzodiazepines are detected in $50-80 \%$ of heroin-related deaths and in $40-80 \%$ of methadone-related deaths in various countries around the world [7]. Benzodiazepines also account for around $28-45 \%$ of drug induced deaths in Europe [2]. A study of 1500 people in 2014 used an internet-based survey to investigate the reasons for the abuse of benzodiazepines and Z-drugs in the United Kingdom (Z-drugs such as zopiclone and zolpidem are structurally different from benzodiazepines but also act via the $\gamma$-aminobuytric acid type-A $\left(\mathrm{GABA}_{\mathrm{A}}\right)$ receptor). The study found that the majority of abuse of Z-drugs and 
benzodiazepines occurred because users were trying to alleviate stress, to help with sleep or to get high [8]. Unfortunately the study did not differentiate between benzodiazepines or Zdrugs but as a result of their similar effects it is likely that they are used interchangeably. When used in combination with other drugs (such as opioids/opiates) the aim of benzodiazepine use is typically to enhance and/or prolong the high or to reduce the withdrawal effects of the other drugs [9].

Outside normal prescription methods, benzodiazepines are obtained via various routes such as diversion of prescriptions, the illicit market and internet purchasing which is thought to be a rising trend [10]. In 2016 the Research and Development (RAND) corporation published a report suggesting that the UK had the second largest number of online vendors of illegal drugs on the darknet (with the US first) but that UK vendors averaged the most transactions per month [11].

In recent years an increasing number of new psychoactive substances (NPS) benzodiazepines have appeared for sale in various countries. NPS are defined by the United Nations Office on Drugs and Crime as "substances of abuse, either in a pure form or a preparation, that are not controlled by the 1961 Single Convention on Narcotic Drugs or the 1971 Convention on Psychotropic Substances, but which may pose a public health threat."[12]. These new psychoactive substances are often sold online and labelled for use as 'research chemicals' only, even though they are implicitly intended for human consumption. Many of these NPSbenzodiazepines have never undergone the clinical testing that is required of licenced medicines and the increasing availability of them may therefore pose serious health risks to poly drug users and benzodiazepine-dependent patients who can no longer obtain their prescription and may turn to other means of obtaining benzodiazepines. We introduce the general way that benzodiazepines are commonly classified (duration of action, half-life and chemical structure) the mechanism of action of benzodiazepines and review what is known to 
date about these NPS-benzodiazepines including user experiences, their pharmacology, pharmacokinetics and analytical detection. This data is summarised in Error! Reference source not found. and was obtained from a variety of published journal articles except the user experiences which were obtained from chat and comments on internet forums such as Reddit [13], Bluelight [14], Flashback [15] and UK Chemical Research [16]. Caution should be taken when interpreting these user experiences as any experiences are subjective and users may have ingested other compounds at the same time. Instead they serve as a rough guide as to the likely effects that may be expected.

\section{The rise of the NPS-benzodiazepines}

The first illicit benzodiazepines identified in Europe to the EMCDDA were phenazepam (fenazepam) and nimetazepam in 2007 [17]. Phenazepam is a prescription drug in the former Soviet bloc [18] and in the intervening years it was detected in an increasing number of cases around the world [19-25]. This led to it being scheduled in the UK and other countries [2628]. Recently, phenazepam was placed in schedule VI of the 1971 UN Drug control convention [29]. The benzodiazepine-derivative etizolam was the next compound to be detected to the EMCDDA in 2011[30]. It belongs to a class of compounds known as thienodiazepines and is commonly prescribed in Japan [31]. The naming of benzodiazepines and their derivatives is discussed in the next section of this review - "Classification of benzodiazepines". Its appearance mirrored that of phenazepam; a prescription drug in a country outside the UK which subsequently found its way to the UK market. Pyrazolam was the next benzodiazepine to appear on the market and was notable as this was the first benzodiazepine to appear that was not a prescription drug in any country [32]. Following this, multiple benzodiazepines were detected to the EMCDDA that have not been licenced for clinical use anywhere in the world. These benzodiazepines include flubromazepam and 
diclazepam in 2013 [33] along with meclonazepam, nifoxipam and deschloroetizolam (a thienodiazepine) in 2014 [34]. Clonazolam and flubromazolam are also thought to have first appeared in 2014 [10] and were subsequently reported to the EMCDDA. Various other benzodiazepines such as adinazolam, nitrazolam and metizolam (another thienodiazepine) have all been reported to the EMCDDA in the 2015 implementation report [35]. Two other benzodiazepines, 3-hydroxyphenazepam (a metabolite of phenazepam [18]) and flutazolam (a Japanese prescription drug [36]) have been detected separately in tablets seized in Sweden in 2015 by the Medical Products Agency (MPA), with the use and spread of flutazolam being monitored and 3-hydroxyphenazepam being subject to an investigation by the MPA [37]. Flunitrazolam, desmethylflunitrazepam (also known as fonazepam) and cloniprazepam were also detected by the MPA in 2016 [38]. Bromazolam [39], desalkylflurazepam (also known as fludiazepam or norflurazepam) [39] and 4-chlorodiazepam (also known as Ro5-4864) [40] are also thought to have appeared at various points in 2016. The years that these benzodiazepines appeared and their year of patient (if available) has been summarised in Table 2 and the timeline can be viewed in Figure 1. Currently hundreds of benzodiazepines have been patented and described in the scientific literature and these are not expected to be the last benzodiazepines that are detected in the so called "explosion" of new psychoactive substances.

NPS-benzodiazepines and thienodiazepines have been implicated in nine drug-related deaths in England and Wales between 2013 - 2014 as either being the cause of death or having contributed to death [41]. In 2016, the Psychoactive Substances Act was introduced in the UK [42] with the aim of stopping the "cat and mouse" game of a NPS being produced to circumvent legislation, being controlled and then another being produced. This legislation restricts the production, sale and supply of drugs that are "psychoactive". It is expected following the introduction of this Act that a fall in supply and use of NPS-benzodiazepines 
may be expected. However, phenazepam and etizolam are now both controlled benzodiazepines in the UK under the Misuse of Drugs Act (1971) [43] but are still regularly identified in post mortem cases and in drug-impaired drivers in the UK [21, 22].

\section{Classification of benzodiazepines}

Benzodiazepines have traditionally been classified in one of three ways, either by;

1) Their duration of action. Benzodiazepines that have durations of action under 24 hours are short-acting while those with durations of action above 24 hours are long-acting [44].

2) Their elimination half-life $\left(\mathrm{t}^{1} / 2\right)$. Typically, this is consists of four classifications; ultrashort $\left(\mathrm{t}^{1} 1 / 2,<6 \mathrm{~h}\right)$, short $\left(\mathrm{t}^{1} / 2,6 \mathrm{~h}\right)$, intermediate $\left(\mathrm{t}^{1 / 2} 6-24 \mathrm{~h}\right)$ and long $\left(\mathrm{t}^{1} / 2>24 \mathrm{~h}\right)$. The reason for these four classifications is because the duration of action of the benzodiazepines can be extended by active metabolites [45-47].

3) Their chemical structure. The core structure of benzodiazepines is a diazepine ring fused to a benzene ring. A phenyl ring is usually attached to the diazepine ring (Figure 2). Most common benzodiazepines are 1,4-benzodiazepines (Figure 2A) (e.g. diazepam [46]) but 1,5benzodiazepines (Figure 2B) (e.g. clobazam [48]) also exist. A whole host of derivatives of this basic benzodiazepine structure are possible. Some of them involve the addition of another cyclic system to the molecule, for example a triazole ring (Figure 2C) (e.g. alprazolam [49]), imidazole ring (Figure 2D) (e.g. midazolam [50]) or oxazole ring (Figure 2E) (e.g. cloxazolam [51]). Others involve replacement of the benzene ring with a thiophene or pyridine ring. One such group of benzodiazepine derivatives are the thienodiazepines (e.g. etizolam [52]) (Figure 2F). They differ in structure by the replacement of a benzene ring with a thiophene ring but they have similar anticonvulsant, anxiolytic and sedative properties [5254]. Thienotriazolodiazepines (Figure 2G) (e.g. brotizolam [54]) have a triazole ring fused to 
the diazepine ring, much like the triazolobenzodiazepines. 2,3-benzodiazepines such as tofisopam exist [55] (Figure 2H) but despite them having the benzodiazepine ring structure they exhibit different pharmacological properties compared with the other benzodiazepines; they act via the 2-amino-3-(3-hydroxy-5-methylisoxazol-4-yl)propionic acid (AMPA) glutamate receptor but still exhibit anxiolytic activity [56, 57]. To the best of the authors' knowledge there are no reports of abuse of 2,3-benzodiazepines. It may only be possible to classify the NPS-benzodiazepines by structure until more information becomes available. Despite being structurally different, thienodiazepines will be grouped together with benzodiazepines as "NPS-benzodiazepines" in this review.

\section{Mechanism of action of benzodiazepines}

The main sites of action of benzodiazepines in the human body are gamma-Aminobutyric acid $A\left(G_{A B A}\right)$ receptors. $G_{A B A}$ receptors are ligand-gated ion channels which are endogenously activated by gamma-Aminobutyric acid (GABA), the major inhibitor neurotransmitter in the central nervous system (CNS) [58]. Their structure consists of five protein subunits that surround a central pore through which $\mathrm{Cl}^{-}$ions can permeate [58]. Binding of GABA to the receptor triggers the chloride ion pore to open leading to an inhibition of neural signals. There are seven receptor subunit families $(\alpha 1-6, \beta 1-3 \gamma 1-3, \delta$, $\varepsilon, \pi, \theta)$ but the most common $\mathrm{GABA}_{\mathrm{A}}$ receptor combination is $\alpha 2 \beta 2 \gamma$, which comprises around $43 \%$ of all $\mathrm{GABA}_{\mathrm{A}}$ receptors in the CNS, with 10 other combinations also identified $[59,60]$. These isoforms are preferentially distributed within specific regions of the CNS [61]. As a result, the receptors have different pharmacological properties and this helps to explain the differing pharmacological effects observed with the benzodiazepines. The role of $\mathrm{GABA}_{\mathrm{A}}$ receptor subunits and addiction has been reviewed by Tan and colleagues[62], with the $\alpha 1$ subunit containing $\mathrm{GABA}_{\mathrm{A}}$ receptors thought to be those that are involved in the 
addictive properties of benzodiazepines [62-64]. Benzodiazepines bind between the $\alpha 1$ and $\gamma 2$ subunits at a site that is distinct from the GABA binding site. They act as positive allosteric modulators, increasing the affinity of GABA to the receptor and potentiating the response of the receptor to GABA [65]. Ethanol also binds to the $\mathrm{GABA}_{\mathrm{A}}$ receptor [66] as do another class of drugs, the barbiturates [67]. An exception to the benzodiazepines binding to the $\mathrm{GABA}_{\mathrm{A}}$ receptor can be found for 4-chlorodiazepam (Ro5-4864) which recently appeared as an NPS-benzodiazepine [40]. 4-chlorodiazepam binds exclusively to the translocator protein $(18 \mathrm{kDa})$ (TSPO $18 \mathrm{kDa})$ [68], initially known as the peripheral benzodiazepine receptor [69]. TSPO $(18 \mathrm{kDa})$ is found throughout the body and has a variety of biological functions which have been extensively reviewed [69-71] and it is thought to have considerable potential therapeutic value as a pharmacological target [72, 73]. Certain compounds that bind to TSPO (18 kDa) can exhibit typical benzodiazepine effects such as being anxiolytic without causing some side effects associated with benzodiazepine use such as sedation [74]. However 4-chlorodiazepam has been found to induce anxiety and cause convulsions in rats despite being a sedative $[75,76]$. Other benzodiazepines such as diazepam also experience some binding to TSPO $(18 \mathrm{kDa})[70,77]$ but the majority of their pharmacological effects result from the binding of them to $\mathrm{GABA}_{\mathrm{A}}$ receptors [71].

\section{Benzodiazepine pharmacokinetics}

The pharmacokinetics of benzodiazepines vary widely. The most common route of administration for prescription benzodiazepines is orally but they are also given intramuscularly, intravenously or rectally [44]. When administered orally there is a wide variation between the time taken to reach $t_{\max }$ [44]. For example the NPS-benzodiazepine phenazepam reaches a $t_{\max }$ between $2-4$ hours following a $2 \mathrm{mg}$ dose [78] while flubromazepam is only thought to reach $\mathrm{t}_{\max }$ after 11.8 hours following a $4 \mathrm{mg}$ dose [79]. The 
time of day that benzodiazepines are administered can affect $t_{\max }$; triazolam exhibits a $t_{\max }$ of $\sim 13$ minutes when taken in the morning compared with $\sim 22$ minutes when taken in the evening and the half-life $\left(t_{1 / 2}\right)$ was similarly affected (2.94 hours in the morning versus 3.77 hours in the evening) [80]. It was thought that this is as a result of the longer fasting period prior to the dose [80].

Benzodiazepines can have vastly differing half-lives and this has been well reviewed [44]. An important point of note is that the half-life of active benzodiazepine metabolites can be far greater than that of the parent benzodiazepine. For example, desmethyldiazepam (marketed as nordazepam) is an active metabolite of several benzodiazepines and can have a half-life of $96 \pm 34$ hours following oral administration of prazepam [45] or 120 hours following diazepam [46]. Similarly, desalkylflurazepam is the active metabolite of flurazepam and can have a half-life of $40-144$ hours following oral administration [47]. Desalkylflurazepam is now known to be sold as a novel psychoactive substance [39]. The main monohydroxylated metabolite of the NPS-benzodiazepine flubromazepam can be detected in urine up to 28 days following ingestion compared to 6 days and 20 hours for the parent compound indicating a higher half-life for the metabolite [79]. Similarly, diclazepam is found only in very low concentrations in serum and urine for just over four days. However its metabolites are detectable for longer time periods; delorazepam is detectable for 6 days in urine and 10 days in serum, lorazepam is detectable for 19 days in both serum and urine and lormetazepam is detectable for 11 days in urine [81].

As well as the variations discussed for maximum plasma concentrations and half-lives, other pharmacokinetic parameters exhibit large differences for the benzodiazepines. For example triazolam has a bioavailability of $44 \%$ [82] versus a bioavailability of $97 \%$ for diazepam [83], diazepam is $97 \%$ bound to plasma proteins [84] while alprazolam is only $70 \%$ bound to plasma proteins [85]. Volumes of distribution also differ; oxazepam and the NPS- 
benzodiazepine flubromazepam have relatively low volumes of distribution $\left(0.271 \mathrm{~kg}^{-1}\right.$ [86] and $0.73 \mathrm{l} \mathrm{kg}^{-1}$ [79] respectively) versus a high volume of distribution of $4.4 \mathrm{l} \mathrm{kg}^{-1}$ for flunitrazepam [87].

The differences briefly mentioned above mean that the pharmacokinetics of benzodiazepines cannot be easily compared and specific knowledge of their individual pharmacokinetic parameters is required to understand how they behave in the body. Typical blood concentrations, half-lives and volumes of distribution (where known) for the NPSbenzodiazepines is provided in Table 1 .

The majority of drug metabolism occurs in the liver, primarily by oxidative metabolism mediated by the cytochrome P450 (CYP450) family of enzymes [88]. CYP3A4 is the enzyme most commonly involved in the metabolism of benzodiazepines [89]. However other enzymes are also involved in the metabolism of benzodiazepines such as; CYP3A5, CYP2C19, CYP2B6, CYP2C18 and CYP2C9 [90]. The CYP3A4 enzyme can also conjugate benzodiazepines containing a nitro group with a glutathione group which can result in cytotoxicity in the liver [89]. Polymorphisms in metabolic enzymes can lead to an alteration in the metabolism of specific drugs. There is only limited evidence that polymorphisms of CYP3A4/5 clinically affect benzodiazepine metabolism [91]. However CYP2C19 polymorphisms have been shown to influence the metabolism of benzodiazepines to a significant degree particularly with clobazam [92], etizolam [93] and diazepam [94, 95]. In one study subjects who were CYP2C19 poor metabolisers exhibited an elimination half-life for diazepam which was twice that of normal metabolisers [96]. The effect of polymorphisms could not only lead to greater toxicity but also a longer detection window after administration. The phase II metabolic pathways of benzodiazepines have been less widely studied but are thought to involve uridine 5'-diphospho-glucuronosyltransferase (UGT) enzymes particularly UGT2B15 [97], UGT1A9 [98], UGT2B7 [98] and UGT1A4 [99]. 
Polymorphisms in N-acetyltransferase 2 (NAT2) enzymes can affect the metabolism of benzodiazepines that undergo $\mathrm{N}$-acetylation. This has been observed for a metabolite of clonazepam, 7-aminoclonazepam, where variant NAT2 polymorphisms caused a reduction in the rate of its metabolism [100].

In order to detect benzodiazepine use it is important to be able to detect the parent drug as well as any metabolites. Depending on the type of benzodiazepine "class" and the additional chemical substituent groups on the core structure the benzodiazepines undergo similar phase I metabolism. The common metabolic pathways for 1,4-benzodiazepines and some triazolo/imidazobenzodiazepines are shown in Figures 3 and 4 respectively. Oxidation is the primary phase I metabolic pathway observed for the majority of benzodiazepines. Typically, this involves hydroxylation on the same carbon atom on the diazepine ring, either labelled as position-3 (e.g. phenazepam [101]) or position 4 (e.g. clonazolam [10]). Hydroxylation at the $\alpha$-position is also thought to occur for some benzodiazepines (e.g. flubromazolam [10]). Ndemethylation of the tertiary amine located on the diazepine ring of diclazepam has been described [81] whilst benzodiazepines containing a nitro group (e.g. meclonazepam [10]) undergo reduction. For phase II metabolism, benzodiazepines that contain hydroxyl groups typically undergo phase II glucuronide conjugation (e.g. lorazepam and oxazepam [102]) without any phase I metabolism. Benzodiazepines containing a 3-hydroxy group typically have a shorter duration of action as they are directly metabolised to glucuronidated forms that are inactive [103]. Some benzodiazepines can be detected as benzophenones (they are either directly metabolised to these compounds or experience some form of physical degradation) in urine after administration of the parent drug (e.g. alprazolam [104], nitrazepam [105], and phenazepam [106]). The structures of the NPS-benzodiazepines are provided in Figures 2A-H and Tables $2-5$ and their metabolic routes are provided in Figures 3, 4 and Table 8. 
Once benzodiazepines are metabolised they are mainly eliminated in urine with between $<1$ $\%$ to $\sim 20 \%$ of the parent drug excreted unchanged with glucuronide being the most common metabolite [44]. As benzodiazepines follow common patterns it should be possible to predict the likely metabolites and routes of elimination of the NPS-benzodiazepines.

In order to detect the use of NPS-benzodiazepines, give appropriate clinical treatment people who have been exposed to the NPS-benzodiazepines and to interpret their blood/plasma concentrations it is important to have pharmacokinetic, analytical and clinical data. With this in mind we have collated the current available data on the NPS-benzodiazepines within this review.

\section{Analytical Detection of NPS-benzodiazepines}

It is important in toxicological analysis that analytical methodology is able to detect, identify and quantify drugs in a large number of matrices. As benzodiazepines are routinely used in clinical practice throughout the world, a large number of methods exist for their detection and quantification. The analytical methodologies for the determination of benzodiazepines in biological samples (blood, plasma, vitreous, oral fluid, hair, nails and others) have been recently reviewed $[107,108]$. It is also important to understand whether analytical methodologies are likely to detect previously unknown benzodiazepines. The common methodological sequence during systematic toxicological analysis is detection, identification and then finally quantitation [109]. Toxicology laboratories commonly utilise immunoassays for presumptive detection before confirmation with other analytical techniques as a result of the large numbers of samples they may acquire. The advantage of the use of an immunoassay for screening is the lack of absolute selectivity of immunoassay antibodies that target the general structure of drug (such as benzodiazepines) rather that the specific drug (such as diazepam or phenazepam) [110]. Two recent publications investigating the cross reactivity of 
standard commercial immunoassay drug screening to new NPS benzodiazepines in both blood and urine have shown that new NPS benzodiazepines would be detected by current immunoassay screens $[111,112]$. Potential misidentification could occur however for structural isomers such as diclazepam and 4-chlorodiazepam (Ro5-4864) [113]. It is likely that new, as yet unknown, benzodiazepines would be detected by current commercial benzodiazepine immunoassays. This hypothesis was backed up by data from the Swedish STRADA project (a project that monitors the occurrence and trends of new psychoactive substances) where 390 clinical samples tested positive in a benzodiazepine immunoassay screen and subsequently tested negative in a classical LC-MS/MS benzodiazepine screen. Later, $40 \%$ of these samples were confirmed as containing NPS-benzodiazepines [114]. Following the presumptive detection of benzodiazepines confirmation and quantitation are needed. Typically HPLC $[115,116]$ with or without a mass spectrometer is used but GC-MS [117, 118] and capillary electrophoresis [119] have been utilised. As the NPSbenzodiazepines are extremely similar in structure to clinically used benzodiazepines it is expected that they would be able to be detected using similar methods. LC-TOF-MS currently gives the best methodology for the detection of any emerging NPS benzodiazepines as it is possible to search for compounds based on the molecular formula alone [120] although care needs to be taken with any isomers that may lead to misidentification. Sample preparation is an important step in the detection and quantitation of NPS benzodiazepines. The two common techniques used are that of liquid-liquid extraction (LLE) and solid phase extraction (SPE) [109]. SPE gives advantages amongst others of higher selectivity and increased extraction efficiency and recovery over LLE [121]. This could however be a disadvantage when trying to identify new compounds that have not previously been detected and may not elute from a specific SPE column. 
One SPE technique that is becoming increasingly popular is the quick, easy, cheap, effective, rugged, safe (QuEChERS) dispersive SPE (dSPE) technique [122]. The use of a primary and secondary amine phase (PSA) allows easier removal of complex matrix components such as blood [123]. The QuEChERS technique has been shown to increase the recoveries of benzodiazepines extracted from various biological matrices such as blood and urine [124] and also from milk-based alcoholic drinks (where benzodiazepines are often added illicitly) which provides a complex matrix for extraction as a result of the high number of proteins and fatty acids [125].

The methods that are currently available for the detection and quantitation of NPS benzodiazepines in body fluids are listed in Table 7. LC-MS has been used to detect both flubromazepam and its metabolites in urine and serum [79] and also pyrazolam [126]. Pyrazolam does not appear to produce metabolites according to one study [126] but is detectable in serum for up to 50 hours but it is excreted in urine for up to 6 days following ingestion of $1 \mathrm{mg}$ which provides a fairly large window of detection for analysis [126]. Diclazepam is found only in very low concentrations for just over four days following ingestion of $1 \mathrm{mg}$ [81]. However its metabolites are discernible for longer time periods with delorazepam detectable for 6 days in urine and 10 days in serum, lorazepam 19 days in both serum and urine and lormetazepam 11 days in urine [81]. Flubromazepam and its metabolites also exhibit a low level of detection in urine using immunoassays [79] [127] [112]. However, by the use of LC-MS, the monohydroxylated metabolite was detectable for 28 days following ingestion in the urine samples, compared with 23 days in the plasma samples providing an extremely long window of detection for the drug [79]. Other NPS-benzodiazepines would be expected to be similarly detectable.

The metabolic pathways for benzodiazepines are fairly similar (see Figures 3 and 4) and this allows metabolites to be predicted and actively searched for when analysing samples using 
techniques such as LC-MS [128, 129]. As a result of the aforementioned similar metabolic pathways, care must be taken when interpreting the apparent presence of a metabolite. For example, diclazepam is metabolised to lorazepam, lormetazepam and delorazepam which are all prescription drugs [81]. Likewise 3-hydroxyphenazepam has been sold on its own as an NPS-benzodiazepine but is a metabolite from both phenazepam [18] and a Russian prescription benzodiazepine cinazepam [130]. Desalkylflurazepam is a metabolite of several drugs including flurazepam [131], midazolam [132] and the Japanese prescription drugs flutoprazepam [133] and fludiazepam [134].

\section{NPS Benzodiazepine Stability}

With any detection, identification and quantification of a drug it is important to have information on the stability of the drug and any possible changes in the drug concentration that may happen during transportation and/or storage [135]. There have been numerous studies on the stability of benzodiazepines in matrices such as blood and urine at temperatures from $20{ }^{\circ} \mathrm{C}$ to $-80{ }^{\circ} \mathrm{C}$ [136-139]. Nitrobenzodiazepines (such as flunitrazepam, clonazepam and nitrazepam) and chlordiazepoxide have been found to be the most unstable especially in bacterially-contaminated specimens $[136,140]$. Two studies have been carried out investigating the stability of NPS benzodiazepines (pyrazolam, diclazepam, flubromazepam, meclonazepam, phenazepam, etizolam, nifoxipam, deschloroetizolam, clonazolam, flubromazolam and flutazolam) but only in urine for 1 month and 7 months [128, 141]. These studies showed that flubromazepam, clonazolam, nifoxipam and meclonazepam (the latter three are nitrobenzodiazepines) were unstable in urine (at ambient temperature and at $-4{ }^{\circ} \mathrm{C}$ ). Meclonazepam was only detected at $8 \%$ of its original concentration after 4 weeks

at $-4{ }^{\circ} \mathrm{C}$ and $-20{ }^{\circ} \mathrm{C}$ after 4 weeks). Meclonazepam has also been shown to be unstable in plasma in glass, but not in polypropylene tubes at $-20{ }^{\circ} \mathrm{C}[142]$. These studies indicate that 
any future nitrobenzodiazepines are likely to be unstable and suggest that all NPS benzodiazepines should be investigated for stability and that they should all be collected in tubes containing fluoride oxalate $(1 \%)$ and then stored at the lowest temperature possible (ideally $-20^{\circ} \mathrm{C}$ or lower) before analysis.

\section{Prediction of the pharmacological, toxicological and pharmacokinetic properties of benzodiazepines.}

The lack of both in vivo and in vitro pharmacological testing of the new psychoactive substances that are emerging can be overcome to an extent with the use of quantitative structure activity relationship (QSAR) modelling. This technique creates a model that relates biological activity to structural descriptors of the compound and is based on a learning set with known biological activity. Systematic in vivo and in vitro work has also been carried out in order to investigate the structural characteristics that relate to pharmacological activity. From these studies estimations of activity of novel 1,4-benzodiazepines (Figure 2A) can be estimated for half-life ( $\left.\mathrm{t}^{1} / 2\right)$, volume of distribution (Vd), bioavailability (F) [143] as well as the potential toxicity of benzodiazepines [144], showing that hydrazone fragments, primary amines and saturated heterocyclic ring systems lead to increases in toxicity [144]. The biological activity of benzodiazepines was initially studied by Hester who determined the effects of substituents on the biological activity. This determined that triazolobenzodiazepines (Figure 2C) were more potent than the corresponding 1,4benzodiazepine [145, 146]. As for the 1,4-benzodiazepines, the R1, R3, R7 and R2' positions (Figure 2A) are important for biological activity [147, 148]. The removal of the phenyl group removes the GABA potentiation by the compound but it can still bind to the GABA site [149]. QSAR studies identified the relative importance of each site to activity and also which functional groups could be added at various positions for optimal biological activity. 
The R7 position was the most important position for increasing receptor affinity $(30 \%$ in the QSAR model) with the 10 optimal functional groups being $\mathrm{CH}_{2} \mathrm{CF}_{3}>\mathrm{I}>\mathrm{Br}>\mathrm{CF}_{3}>\mathrm{Cl}>$ $\mathrm{C}\left(\mathrm{CH}_{3}\right)_{3}>\mathrm{NO}_{2}>\mathrm{F}>\mathrm{N}_{3}>\mathrm{CH}=\mathrm{CH}_{2}$ [150]. At the $\mathrm{R} 1$ position (37\% in the QSAR model) the most optimal groups were $\mathrm{OH}>\mathrm{F}>\mathrm{NH}_{2}>\mathrm{H}>\mathrm{NHOH}>\mathrm{C}_{2} \mathrm{H}_{5}>\mathrm{Cl}>\mathrm{CF}_{3}>\mathrm{Br}>\mathrm{CH}_{3}$ [156] and the tert-butyl substitution led to inactivity [157]. At the R2' position (15\% in the QSAR model) the order of the most optimal groups was $\mathrm{NO}_{2}>\mathrm{F}>\mathrm{CN}>\mathrm{Cl}>\mathrm{CF}_{3}[150$, 151]. The influence that substitution at the R3 position has on biological activity is unclear and difficult to predict as a result of the formation of enantiomeric forms $[152,153]$ but it is thought to have limited influence on the biological activity [154]. In the literature there are measured binding affinities for desmethylflunitrazepam (fonazepam) and meclonazepam (log $\mathrm{IC}_{50}$ ) of 0.176 and 0.079 respectively with predicted values of 0.565 and 0.357 respectively $[152,153]$. These results show that although QSAR can be useful for prediction it is not a replacement for traditional in vivo and in vitro testing.

\section{The composition of illicitly-sold NPS-benzodiazepines}

A major issue with the purchase of drugs online is that there is no guarantee of the quality of composition. Alprazolam is one of the most widely-prescribed benzodiazepines in the world therefore it is not surprising that it is often illicitly sold. However, the wide variety of drugs that are sold and stated to contain alprazolam is both remarkable and concerning. Mimic alprazolam tablets have been found to contain melatonin [155] or the opioid fentanyl [156]. EcstasyData.org is an independent testing laboratory, created primarily to reduce the potential harm of illicit ecstasy by providing data on the composition of ecstasy tablets [157]. However, a variety of other drugs are often sent in and tested. This independent testing laboratory utilises GC-MS, thin layer chromatography (TLC) and colour tests for analysing and identifying the materials that are supplied to them [157]. Other drugs that have been 
found in alprazolam tablets include other clinically-used benzodiazepines, synthetic cannabinoids, synthetic opiates, Z-drugs, piperazines, barbiturates and clinically-used anaesthetics and antihistamines. Clonazepam tablets have been identified as containing the NPS-benzodiazepine clonazolam [157]. Etizolam tablets have been found to contain alprazolam, flubromazepam (an NPS-benzodiazepine) and also diphenylprolinol, a compound used as a designer drug [157]. Diclazepam tablets have been identified as containing nimetazepam [157], a widely-prescribed and abused drug in southeast Asia [158] and an NPS-benzodiazepine in Europe itself [17] and some illicit tablets of nimetazepam (also known as Ermin 5) have been found to contain phenazepam [159]. In addition, in the 2016 EMCDDA drug report it was noted that alprazolam tablets had been identified as containing flubromazolam and diazepam tablets had been identified to contain phenazepam [3]. This is a huge problem for drug users as they may be inadvertently taking a drug potentially many times more harmful than expected as a result of the lack of information regarding drug-drug interactions. As mentioned previously, it is well known that the concurrent use of opioids, opiates and benzodiazepines can increase the risk of death [7, 160]. There have been sporadic reports of the use of benzodiazepines as either diluents or adulterants in heroin however this does not appear to be as common [161]. The majority of the data from EcstasyData.org is from the United States but samples are sent in from across the world with many appearing to have been purchased online in China [157]. With the increase of NPSbenzodiazepines in recent years, this may become even more problematic.

\section{Summary}

The use and abuse of benzodiazepines is already common throughout the world. In recent years there has been a large increase in new psychoactive substances. Benzodiazepines are only a small subsection of the total number of new psychoactive substances but that number 
is steadily increasing. NPS-benzodiazepines are appearing in a variety of countries across the world. NPS-thienodiazepines are appearing at a much slower rate, perhaps as a result of a lower usage clinically and the already widespread availability of benzodiazepines. NPSbenzodiazepines have been implicated in deaths in England and Wales and the increasing availability of all novel psychoactive substances led to the introduction of the Psychoactive Substances Act within the UK in 2016. It remains to be seen whether this will affect the supply and use of NPS-benzodiazepines because phenazepam and etizolam were placed under control in the UK under the Misuse of Drugs Act 1971 but are still regularly identified in post-mortem cases and in drug-impaired drivers within the UK. The same may be expected for the NPS-benzodiazepines. The pharmacokinetics and metabolic pathways of NPSbenzodiazepines are not currently well understood and there can be huge variation in pharmacokinetic parameters between individual compounds. Further investigation is clearly needed to establish the exact pharmacology of these new psychoactive substances. 
Table 1: Pharmacological Details of NPS Benzodiazepines

\begin{tabular}{|c|c|c|c|c|c|c|c|c|}
\hline Drug & Formula & $\mathrm{mW}\left(\mathrm{g} \mathrm{mol}^{-1}\right)$ & $\begin{array}{c}\text { Typical } \\
\text { Recreational } \\
\text { dose (mg) }\end{array}$ & $\begin{array}{c}\text { "Therapeutic"/DUID } \\
\text { range in blood (mg l' } \\
\left.{ }^{1}\right)\end{array}$ & T1/2 (h) & $\operatorname{Vd}\left(1 \mathrm{~kg}^{-1}\right)$ & User reports of effects & Refs \\
\hline 3-hydroxyphenazepam & $\mathrm{C}_{15} \mathrm{H}_{10} \mathrm{BrClN}_{2} \mathrm{O}_{2}$ & 365.6 & $0.5-2$ & - & - & - & $\begin{array}{l}\text { Anxiolytic, slight muscle relaxant, } \\
\text { strongly sedating }\end{array}$ & {$[14,162]$} \\
\hline 4-chlorodiazepam & $\mathrm{C}_{16} \mathrm{H}_{12} \mathrm{Cl}_{2} \mathrm{~N}_{2} \mathrm{O}$ & 319.2 & - & - & - & - & No reports & - \\
\hline Adinazolam & $\mathrm{C}_{19} \mathrm{H}_{18} \mathrm{ClN}_{5}$ & 351.8 & 20 & $0.1-0.46$ & $1-3$ & 2.2 & No reports & {$[163-167]$} \\
\hline Bromazolam & $\mathrm{C}_{17} \mathrm{H}_{13} \mathrm{BrN}_{4}$ & 353.2 & 1 & - & - & - & No reports & - \\
\hline Clonazolam & $\mathrm{C}_{17} \mathrm{H}_{12} \mathrm{ClN}_{5} \mathrm{O}_{2}$ & 353.1 & $0.5-1$ & $0.0019-0.011$ & - & - & Slight euphoria, strongly sedating & {$[168,169]$} \\
\hline Cloniprazepam & $\mathrm{C}_{19} \mathrm{H}_{16} \mathrm{ClN}_{3} \mathrm{O}_{3}$ & 369.8 & 2.5 & - & - & - & $\begin{array}{l}\text { Slight anxiolytic, higher doses ( }>5- \\
10 \mathrm{mg} \text { ) required for muscle } \\
\text { relaxation, sedation in most users }\end{array}$ & [170] \\
\hline Desalkylflurazepam & $\mathrm{C}_{15} \mathrm{H}_{10} \mathrm{ClFN}_{2} \mathrm{O}$ & 288.7 & 5 & - & - & - & $\begin{array}{c}\text { Strongly sedating and long lasting } \\
\text { effects }\end{array}$ & {$[16]$} \\
\hline Deschloroetizolam & $\mathrm{C}_{17} \mathrm{H}_{16} \mathrm{~N}_{4} \mathrm{~S}$ & 308.4 & $4-6$ & - & - & - & $\begin{array}{c}\text { Effects lasting } 12-24 \text { hours, } \\
\text { anxiolytic, sedative effect, slight } \\
\text { euphoria }\end{array}$ & {$[14]$} \\
\hline $\begin{array}{l}\text { Desmethylflunitrazepam } \\
\text { (fonazepam) }\end{array}$ & $\mathrm{C}_{15} \mathrm{H}_{10} \mathrm{FN}_{3} \mathrm{O}_{3}$ & 299.3 & 0.6 & - & - & - & Anxiolytic, muscle relaxant, sedation & {$[171,172]$} \\
\hline Diclazepam & $\mathrm{C}_{16} \mathrm{H}_{12} \mathrm{Cl}_{2} \mathrm{~N}_{2} \mathrm{O}$ & 319.2 & $1-2$ & $0.0021-0.057$ & 42 & - & $\begin{array}{c}\text { Effects lasting } 5-12 \text { hours, } \\
\text { anxiolytic, useful for 'tapering' } \\
\text { dependence of other } \\
\text { benzodiazepines, low cognitive } \\
\text { impairment, low recreational value. }\end{array}$ & $\begin{array}{c}{[81,169]} \\
{[162]}\end{array}$ \\
\hline Etizolam & $\mathrm{C}_{17} \mathrm{H}_{15} \mathrm{ClN}_{4} \mathrm{~S}$ & 342.1 & $0.25-3$ & $0.019-0.17$ & $3.4-7.1$ & 0.91 & $\begin{array}{l}\text { Anxiolytic, euphoric, muscle } \\
\text { relaxant, used as a sleep-aid }\end{array}$ & [169] \\
\hline Flubromazepam & $\mathrm{C}_{15} \mathrm{H}_{10} \mathrm{BrFN}_{2} \mathrm{O}$ & 333.1 & 4 & $0.0047-1.2$ & 106.4 & - & $\begin{array}{l}\text { Effects lasting } 18-24 \text { hours, } \\
\text { anxiolytic, mild euphoria, blackouts, } \\
\text { sedating and muscle relaxant effects, }\end{array}$ & $\begin{array}{c}{[169]} \\
{[88,177]}\end{array}$ \\
\hline
\end{tabular}

This article is protected by copyright. All rights reserved. 


\begin{tabular}{|c|c|c|c|c|c|c|c|c|}
\hline renta & & & & & & & short-term memory loss & \\
\hline Flubromazolam & $\mathrm{C}_{17} \mathrm{H}_{12} \mathrm{BrFN}_{4}$ & 371.2 & $0.15-0.25$ & $0.0048-0.10$ & - & - & $\begin{array}{l}\text { Effects lasting } 12-18 \text { hours, } \\
\text { anxiolytic, high tolerance to lower } \\
\text { doses quickly observed, blackouts } \\
\text { and memory loss, strongly sedating, } \\
\text { higher doses of } 2.5-4 \mathrm{mg} \text { have } \\
\text { effects reported to last up to } 3 \text { days } \\
\text { and strong memory loss and } \\
\text { cognitive impairment. Ingestion of } 3 \\
\text { mg of flubromazolam } 19 \text { hours prior } \\
\text { to hospitalisation has been reported } \\
\text { in a patient. Severe respiratory } \\
\text { failure, hypotension, central nervous } \\
\text { system depression and brain damage } \\
\text { were observed. }\end{array}$ & $\begin{array}{c}{[79,169} \\
173]\end{array}$ \\
\hline Flunitrazolam & $\mathrm{C}_{17} \mathrm{H}_{12} \mathrm{FN}_{5} \mathrm{O}_{2}$ & 337.3 & 0.1 & - & - & - & $\begin{array}{l}\text { Strong sedative, slight amnesia } \\
\text { reported, anxiolytic }\end{array}$ & [168] \\
\hline Flutaz & $\mathrm{C}_{19} \mathrm{H}_{18} \mathrm{ClFN}_{2} \mathrm{O}_{3}$ & 376.8 & $4-12$ & 0.014 & $\sim 3.3$ & $690 \mathrm{~L}$ & $\begin{array}{l}\text { Strong anxiolytic, hypnotic, short } \\
\text { acting ( } 3-4 \text { hours) }\end{array}$ & {$[174,175]$} \\
\hline Meclonazepam & $\mathrm{C}_{16} \mathrm{H}_{12} \mathrm{ClN}_{3} \mathrm{O}_{3}$ & 329.7 & $2-3$ & $0.01-0.1$ & 80 & $100 \mathrm{~L}$ & $\begin{array}{l}\text { Low sedation, anxiolytic, muscle } \\
\text { relaxant }\end{array}$ & $\begin{array}{l}{[10,175} \\
176]\end{array}$ \\
\hline $\begin{array}{c}\text { Metizolam } \\
\text { (desmethyletizolam) }\end{array}$ & $\mathrm{C}_{16} \mathrm{H}_{13} \mathrm{ClN}_{4} \mathrm{~S}$ & 328.8 & 2 & 0.000011 & - & - & $\begin{array}{l}\text { Anxiolytic and muscle relaxant, } \\
\text { effects not as strong as etizolam }\end{array}$ & {$[168,177]$} \\
\hline Nifoxipam & $\mathrm{C}_{15} \mathrm{H}_{10} \mathrm{FN}_{3} \mathrm{O}_{4}$ & 315.3 & $0.5-2$ & - & - & - & $\begin{array}{c}\text { Effects lasting } 12-18 \text { hours, } \\
\text { anxiolytic, moderately sedating, } \\
\text { mild euphoric, High doses can cause } \\
\text { users to feel sleep-deprived, muscle } \\
\text { relaxant }\end{array}$ & {$[175,178]$} \\
\hline Nimetazepam & $\mathrm{C}_{16} \mathrm{H}_{13} \mathrm{~N}_{3} \mathrm{O}_{3}$ & 295.3 & 5 & 0.0000134 & $12-21$ & - & No reports & [179-181] \\
\hline
\end{tabular}

This article is protected by copyright. All rights reserved. 


\begin{tabular}{|c|c|c|c|c|c|c|c|c|}
\hline Nitrazolam & $\mathrm{C}_{17} \mathrm{H}_{13} \mathrm{~N}_{5} \mathrm{O}_{2}$ & 319.3 & $0.5-2$ & - & - & - & $\begin{array}{l}\text { Anxiolytic, hypnotic, strongly } \\
\text { sedating }\end{array}$ & [182] \\
\hline Phenazepam & $\mathrm{C}_{15} \mathrm{H}_{10} \mathrm{BrClN}_{2} \mathrm{O}$ & 349.6 & $0.5-1$ & $0.030-0.070$ & $6-80$ & $4.7-6.0$ & $\begin{array}{l}\text { Anxiolytic, extremely sedating, } \\
\text { short-term memory loss often leads } \\
\text { to users redosing, blackouts at higher } \\
\text { doses, psychotic episodes, insomnia }\end{array}$ & $\begin{array}{l}{[101,118,} \\
168,183]\end{array}$ \\
\hline Pyrazolam & $\mathrm{C}_{16} \mathrm{H}_{12} \mathrm{BrN}_{5}$ & 354.2 & 1 & 0.074 & 17 & - & $\begin{array}{c}\text { Effects lasting } 6-7 \text { hours, } \\
\text { anxiolytic, low sedation, low } \\
\text { hypnotic effect, low recreational } \\
\text { value }\end{array}$ & $\begin{array}{c}{[126]} \\
{[168,169]}\end{array}$ \\
\hline
\end{tabular}

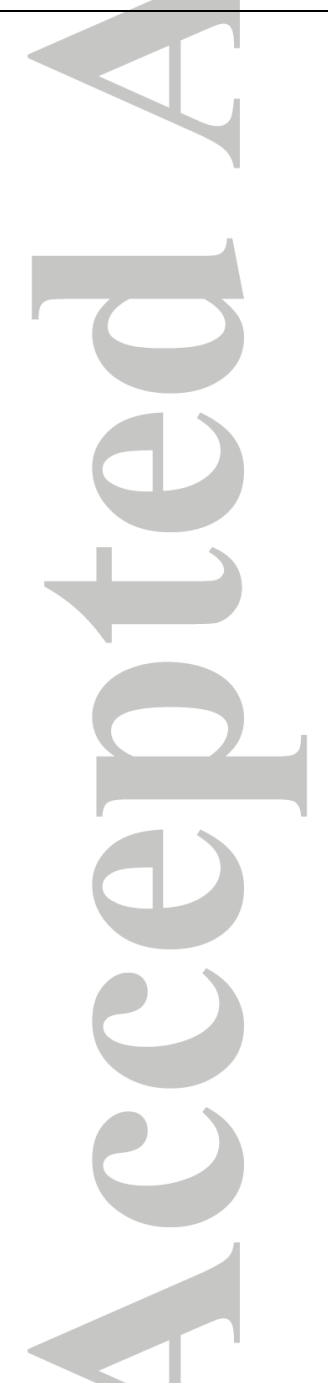

This article is protected by copyright. All rights reserved. 
Figure 1: Timeline of the reporting of NPS-benzodiazepines to the EMCDDA

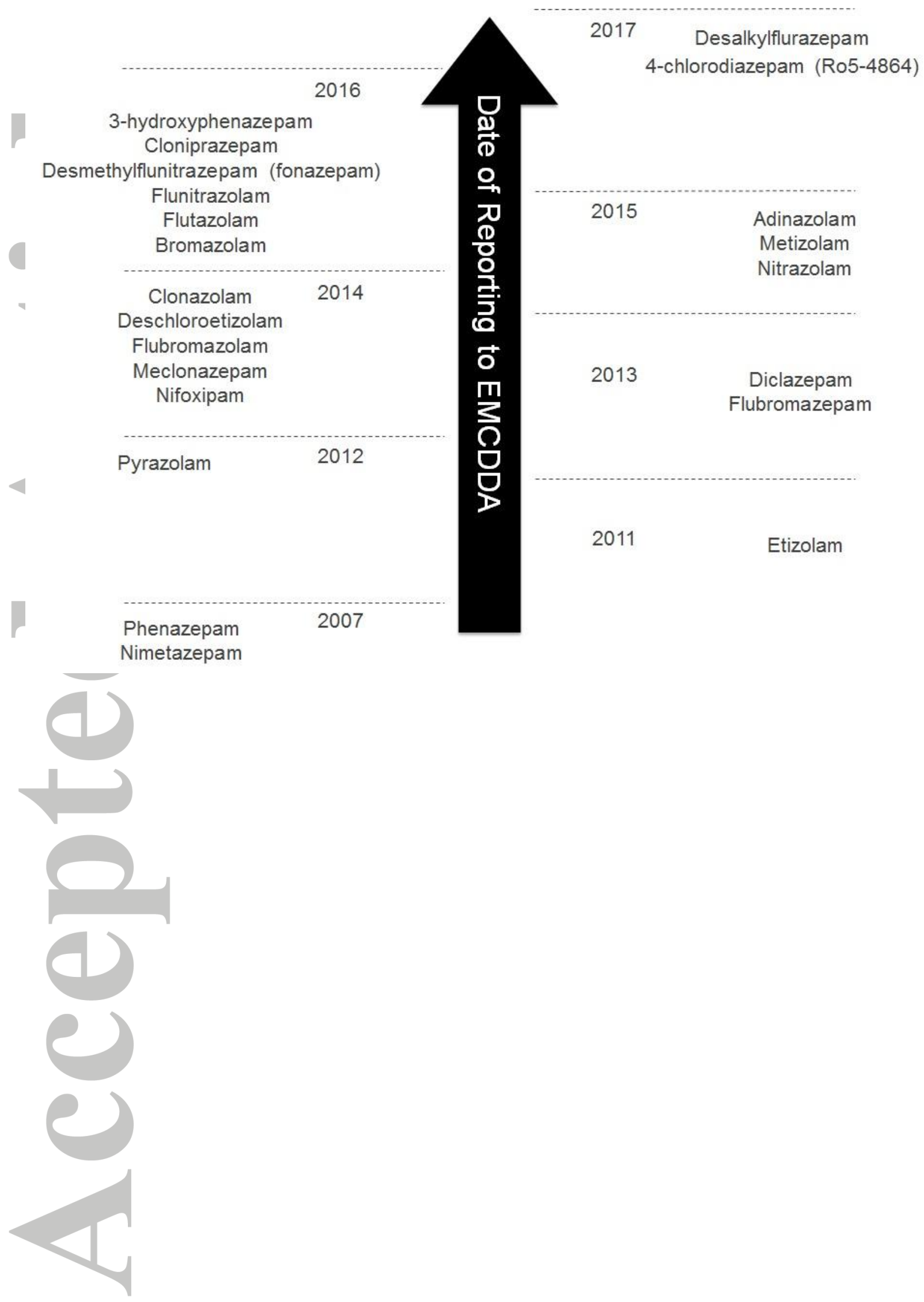

This article is protected by copyright. All rights reserved. 
Table 2: Benzodiazepine patent years and EMCDDA report years

\begin{tabular}{|l|l|l|}
\hline Compound & Year patented & Year reported to the EMCDDA \\
\hline 3-hydroxyphenazepam & Not reported & $2016[46][37]$ \\
\hline 4-chlorodiazepam (Ro5-4864) & $1964[191]$ & $2016[40]$ \\
\hline Adinazolam & $1976[192]$ & $2015[35]$ \\
\hline Bromazolam & $1976[193]$ & $2016[39]$ \\
\hline Clonazolam & $1971[194]$ & $2014[35]$ \\
\hline Cloniprazepam & Not reported & $2015[184]$ \\
\hline Desalkylflurazepam & Not reported & $2016[39]$ \\
\hline Deschloroetizolam & $1998[196]$ & $2014[34]$ \\
\hline Desmethylflunitrazepam \\
(fonazepam) & $1963[197]$ & $2016[38]$ \\
\hline Diclazepam & $1964[198]$ & $2013[33]$ \\
\hline Etizolam & $1978[199]$ & $2011[30]$ \\
\hline Flubromazepam & $1962[200]$ & $2013[33]$ \\
\hline Flubromazolam & $1978[201]$ & $2014[34]$ \\
\hline Flunitrazolam & Not reported & $2016[38]$ \\
\hline Flutazolam & $1970[202]$ & $2015[37]$ \\
\hline Meclonazepam & $1975[203]$ & $2014[34]$ \\
\hline Metizolam & $1988[204]$ & $2015[35]$ \\
\hline Nifoxipam & $1985[205]$ & $2014[34]$ \\
\hline Nimetazepam & $1963[206]$ & $2007[17]$ \\
\hline Nitrazolam & $1971[194]$ & $2015[35]$ \\
\hline Phenazepam & $1974[207]$ & $2007[17]$ \\
\hline Pyrazolam & $1979[208]$ & $2012[32]$ \\
\hline
\end{tabular}


Figure 2A-D: Structure of benzodiazepines and derivatives

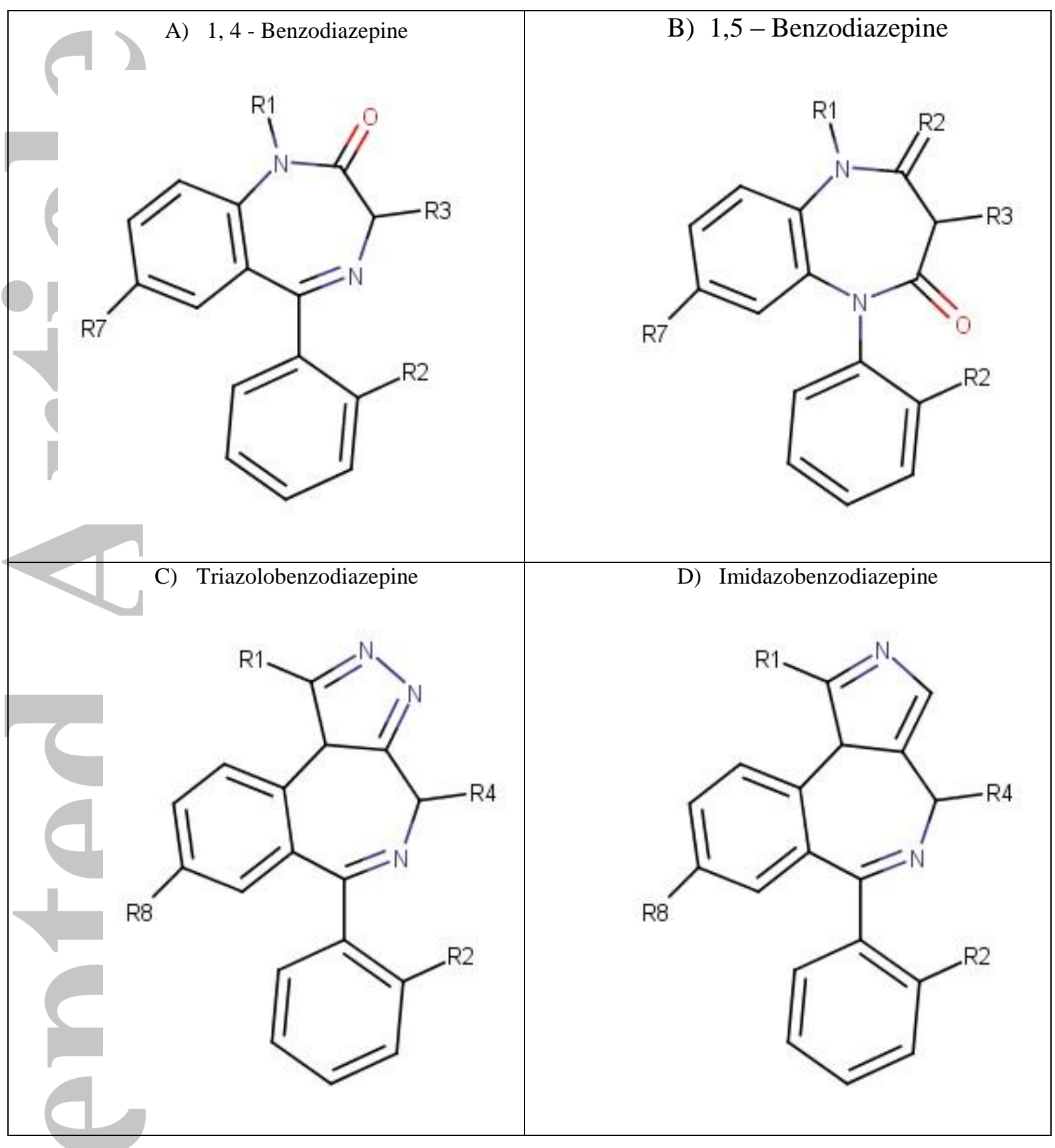

This article is protected by copyright. All rights reserved. 
Figure 2E-H: Structure of benzodiazepines and derivatives

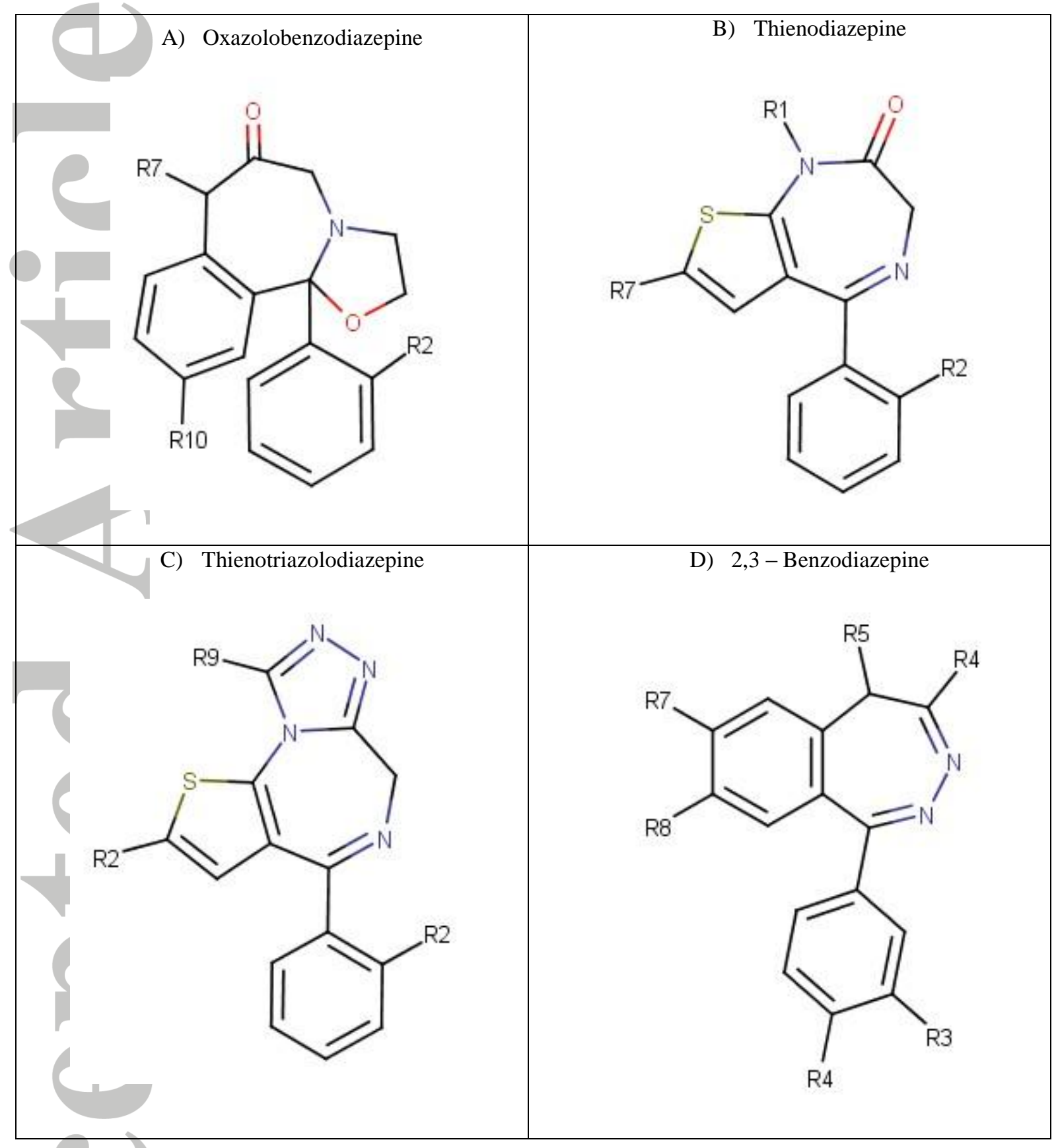

This article is protected by copyright. All rights reserved. 
Table 3: 1,4-benzodiazepine based NPS structures

\begin{tabular}{|l|l|l|l|l|l|}
\hline & \multicolumn{5}{|c|}{ From Figure 2A } \\
\hline Compound & $\mathbf{R}_{\mathbf{1}}$ & $\mathbf{R}_{\mathbf{2}}$, & $\mathbf{R}_{\mathbf{3}}$ & $\mathbf{R}_{\mathbf{7}}$ & \\
\hline 3-hydroxyphenazepam & $\mathrm{H}$ & $\mathrm{Cl}$ & $\mathrm{OH}$ & $\mathrm{Br}$ & \\
\hline $\begin{array}{l}\text { 4-chlorodiazepam (Ro5- } \\
\text { 4864) }\end{array}$ & $\mathrm{CH}_{3}$ & $\mathrm{H}$ & $\mathrm{H}$ & $\mathrm{Cl}$ & $\begin{array}{l}\text { Note: 4-chlorophenyl ring } \\
\text { instead of phenyl ring at } \\
\text { position 6 }\end{array}$ \\
\hline Cloniprazepam & Methylcyclopropane & $\mathrm{Cl}$ & $\mathrm{H}$ & $\mathrm{NO}_{2}$ & \\
\hline Desalkylflurazepam & $\mathrm{H}$ & $\mathrm{F}$ & $\mathrm{H}$ & $\mathrm{Cl}$ & \\
\hline $\begin{array}{l}\text { Desmethylflunitrazepam } \\
\text { (fonazepam) }\end{array}$ & $\mathrm{H}$ & $\mathrm{F}$ & $\mathrm{H}$ & $\mathrm{NO}_{2}$ & \\
\hline Diclazepam & $\mathrm{CH}$ & $\mathrm{Cl}$ & $\mathrm{H}$ & $\mathrm{NO}_{2}$ & \\
\hline Flubromazepam & $\mathrm{H}$ & $\mathrm{F}$ & $\mathrm{H}$ & $\mathrm{Br}_{3}$ & \\
\hline Meclonazepam & $\mathrm{H}$ & $\mathrm{Cl}$ & $\mathrm{CH}$ & $\mathrm{NO}_{2}$ & \\
\hline Nifoxipam & $\mathrm{H}$ & $\mathrm{F}$ & $\mathrm{OH}$ & $\mathrm{NO}_{2}$ & \\
\hline Nimetazepam & $\mathrm{H}$ & $\mathrm{H}$ & $\mathrm{OH}$ & $\mathrm{NO}_{2}$ & \\
\hline Phenazepam & $\mathrm{H}$ & $\mathrm{Cl}$ & $\mathrm{H}$ & $\mathrm{Br}^{2}$ & \\
\hline
\end{tabular}


Table 4: Triazolobenzodiazepine based NPS structures

\begin{tabular}{|l|l|l|l|l|}
\hline & \multicolumn{5}{|c|}{ From Figure 2C } \\
\hline Compound & $\mathrm{R}_{1}$ & $\mathrm{R}_{2}$, & $\mathrm{R}_{8}$ & \\
\hline Adinazolam & $\mathrm{CH}_{2} \mathrm{~N}_{(}\left(\mathrm{CH}_{3}\right)_{2}$ & $\mathrm{H}$ & $\mathrm{Cl}$ & \\
\hline Bromazolam & $\mathrm{CH}_{3}$ & $\mathrm{H}$ & $\mathrm{Br}$ & \\
\hline Clonazolam & $\mathrm{CH}_{3}$ & $\mathrm{Cl}$ & $\mathrm{NO}_{2}$ & \\
\hline Flubromazolam & $\mathrm{CH}_{3}$ & $\mathrm{~F}$ & $\mathrm{Br}$ & \\
\hline Flunitrazolam & $\mathrm{CH}_{3}$ & $\mathrm{~F}$ & $\mathrm{NO}_{2}$ & \\
\hline Nitrazolam & $\mathrm{CH}_{3}$ & $\mathrm{H}$ & $\mathrm{NO}_{2}$ & \\
\hline Pyrazolam & $\mathrm{CH}_{3}$ & None & $\mathrm{Br}$ & $\begin{array}{l}\text { Note: pyridine ring instead of } \\
\text { phenyl ring at position 6 }\end{array}$ \\
\hline
\end{tabular}


Table 5: Thienotriazolodiazepine based NPS structures

\begin{tabular}{|l|l|l|l|}
\hline & \multicolumn{3}{|c|}{ From Figure 2G } \\
\hline Compound & $\mathrm{R}_{2}$ & $\mathrm{R}_{2}$, & $\mathrm{R}_{9}$ \\
\hline Deschloroetizolam & $\mathrm{CH}_{2} \mathrm{CH}_{3}$ & $\mathrm{H}$ & $\mathrm{CH}_{3}$ \\
\hline Etizolam & $\mathrm{CH}_{2} \mathrm{CH}_{3}$ & $\mathrm{Cl}$ & $\mathrm{CH}_{3}$ \\
\hline Metizolam & $\mathrm{CH}_{2} \mathrm{CH}_{3}$ & $\mathrm{Cl}$ & $\mathrm{H}$ \\
\hline
\end{tabular}
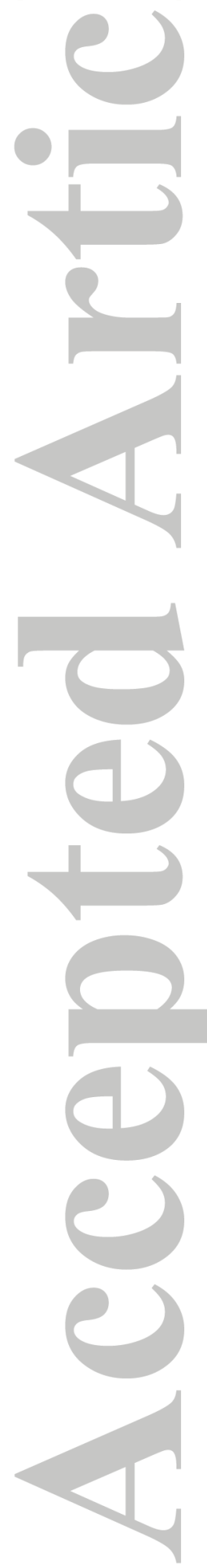

This article is protected by copyright. All rights reserved. 
Table 6: Oxazolobenzodiazepine based NPS structures

\begin{tabular}{|l|l|l|l|}
\hline & \multicolumn{3}{|c|}{ From Figure 2E } \\
\hline Compound & $\mathrm{R}_{2}$ & $\mathrm{R}_{7}$ & $\mathrm{R}_{10}$ \\
\hline Flutazolam & $\mathrm{F}$ & $\mathrm{CH}_{2} \mathrm{CH}_{2} \mathrm{OH}$ & $\mathrm{Cl}$ \\
\hline
\end{tabular}
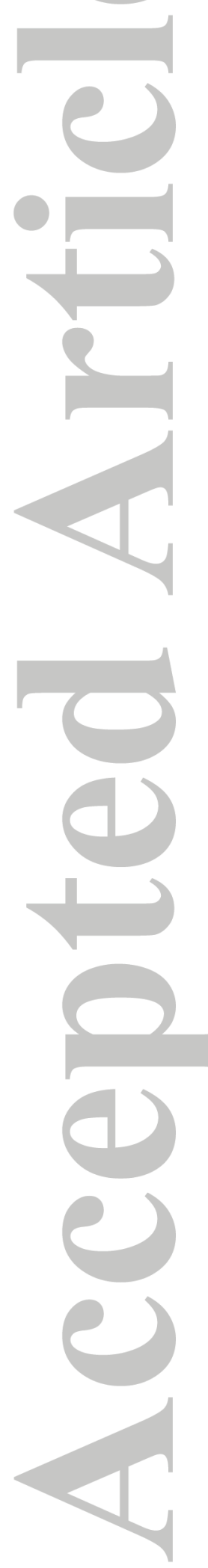

Page 31 of 49

This article is protected by copyright. All rights reserved. 
Figure 3: General metabolic pathways for 1,4-benzodiazepines
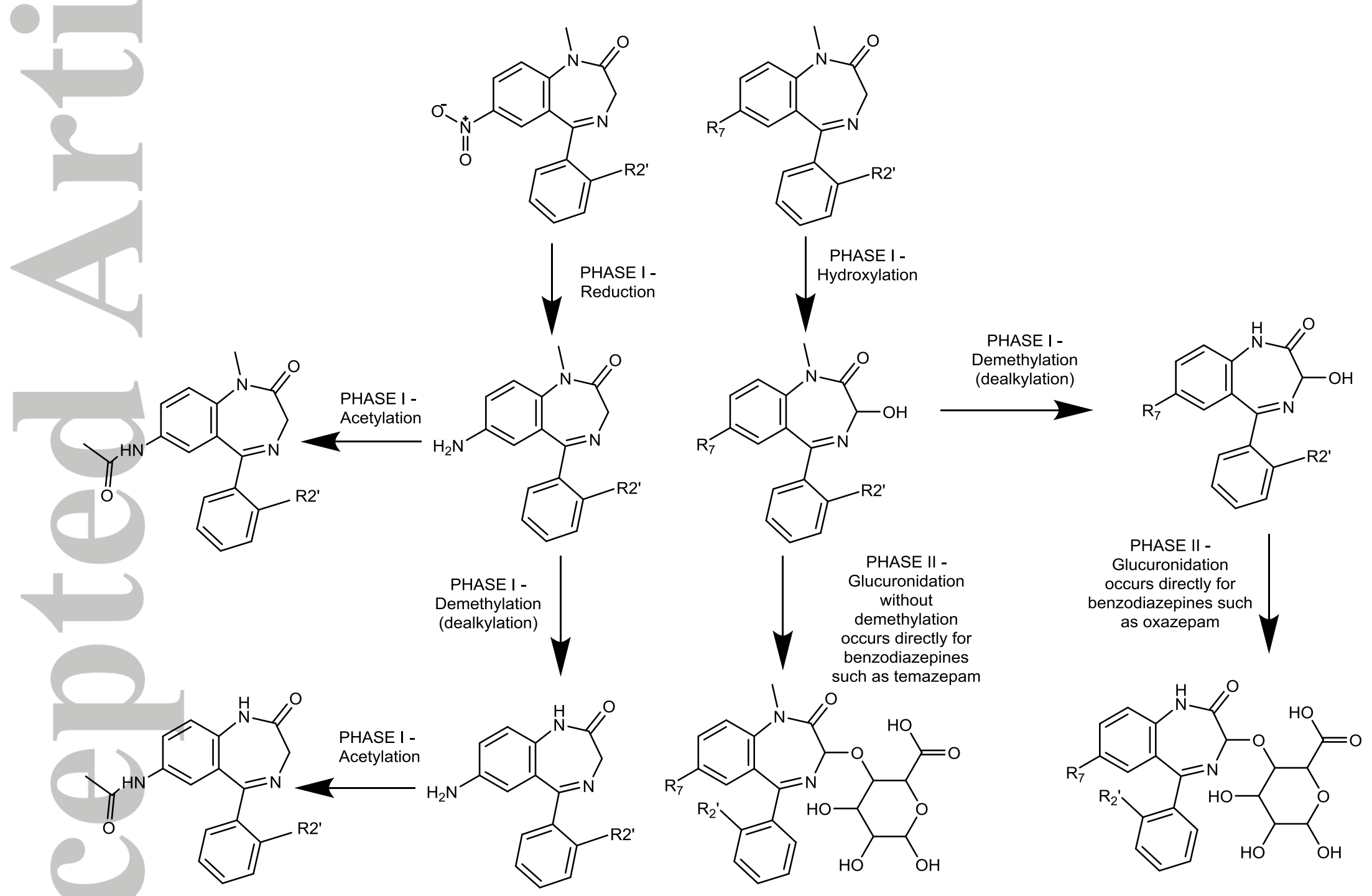

Page 32 of 49

This article is protected by copyright. All rights reserved. 
Figure 4: General metabolic pathways for triazolobenzodiazepines (also applies to imidazobenzodiazepines)

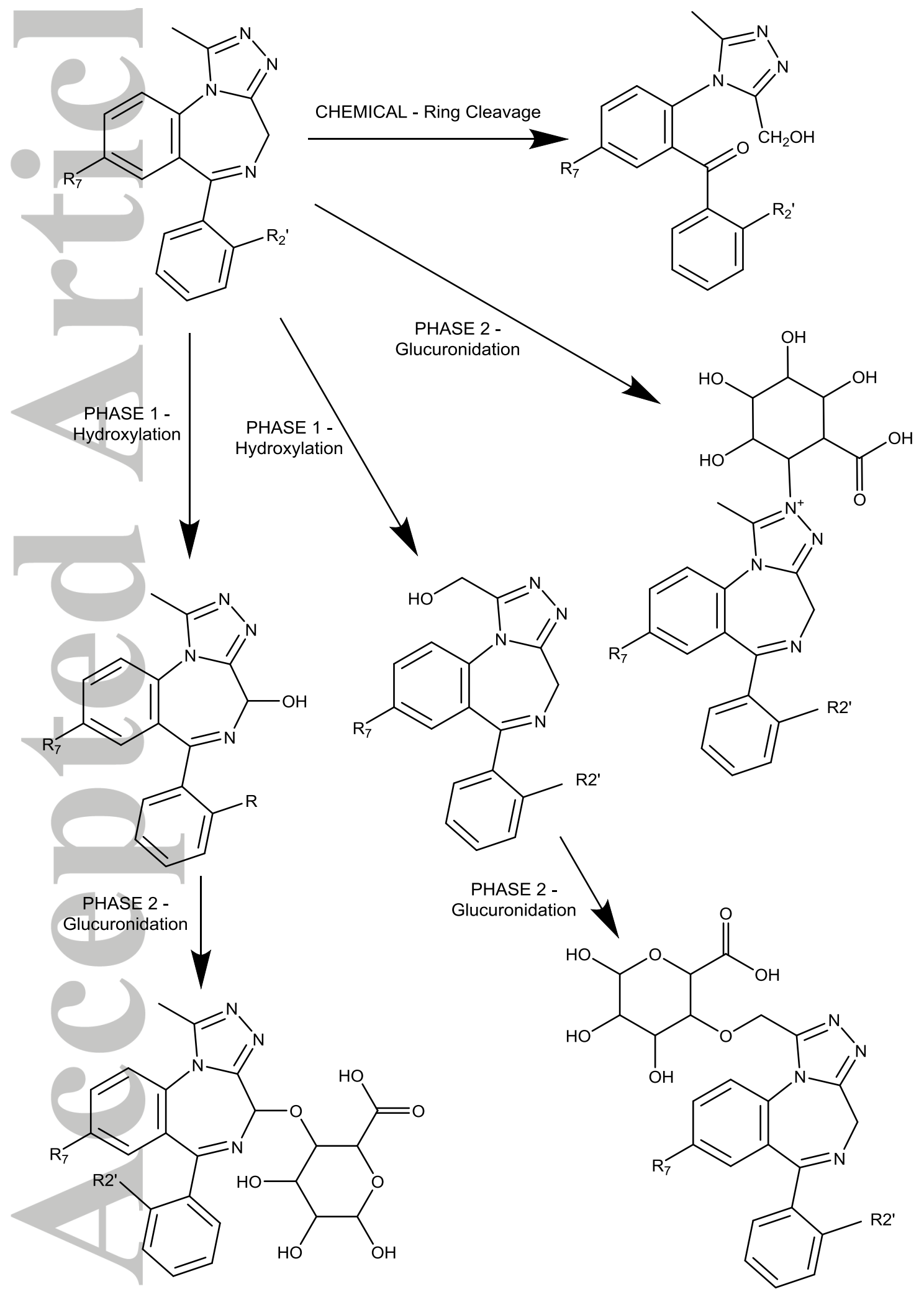

This article is protected by copyright. All rights reserved. 
Table 7: Analytical methods for the analysis of NPS-benzodiazepines in biological matrices

\begin{tabular}{|c|c|c|c|c|c|c|c|c|}
\hline Analyte & Matrix & Analytical Method & Internal Standard & Extraction & $\begin{array}{l}\text { Limit of } \\
\text { detection } \\
\left(\mathrm{ng} \mathrm{ml}^{-1}\right)\end{array}$ & $\begin{array}{c}\text { Linear range } \\
\quad\left(\mathrm{ng} \mathrm{ml}^{-1}\right)\end{array}$ & $\begin{array}{l}\text { Limit of quantitation } \\
\qquad\left(\mathrm{ng} \mathrm{ml}^{-1}\right)\end{array}$ & Ref. \\
\hline Adinazolam & Plasma & HPLC-UV & Alprazolam & LLE (ethyl acetate) & $\sim 5$ & $10-800$ & 10 & [185] \\
\hline $\begin{array}{l}\text { 3-hydroxyphenazpem } \\
\text { Phenazepam }\end{array}$ & $\begin{array}{l}\text { Blood } \\
\text { Urine } \\
\text { Vitreous } \\
\text { Muscle } \\
\text { Brain } \\
\text { Liver }\end{array}$ & LC-MS/MS & Diazepam-d5 & $\begin{array}{c}\text { LLE } \\
\text { (hexane:ethylacetate } \\
7: 3 \text { ) }\end{array}$ & $\begin{array}{c}0.3 \\
7\end{array}$ & $\begin{array}{l}16-100 \\
0.7-200\end{array}$ & $\begin{array}{l}0.7 \\
16\end{array}$ & [162] \\
\hline $\begin{array}{l}\text { Clonazolam } \\
\text { Meclonazepam } \\
\text { Nifoxipam }\end{array}$ & Urine & LC-MS & $\begin{array}{l}\text { Methamphetamine-d5 } \\
\text { Pethidine-d4 }\end{array}$ & LLE & Not provided & Not provided & Not provided & [186] \\
\hline $\begin{array}{l}\text { Clonazolam, } \\
\text { Diclazepam } \\
\text { Etizolam } \\
\text { Flubormazepam } \\
\text { Flubromazolam } \\
\text { Pyrazolam }\end{array}$ & Blood & UPLC-MS/MS & Diazepam-d5 & $\begin{array}{c}\text { LLE } \\
\text { (ethyl } \\
\text { acetate:heptane 4:1) }\end{array}$ & Same as LOQ & Not provided & $\begin{array}{c}1.4 \\
1.6 \\
1.4 \\
3.3 \\
0.37 \\
3.5\end{array}$ & [169] \\
\hline $\begin{array}{c}\text { Pyrazolam } \\
\text { Dicalzepam } \\
\text { Flubormazepam } \\
\text { Meclonazepam } \\
\text { Phenazepam } \\
\text { Etizolam } \\
\text { Nifoxipam } \\
\text { Deschloroetizolam } \\
\text { Clonazolam } \\
\text { Flubromazolam } \\
\text { Flutazolam }\end{array}$ & Urine & LC-MS/MS & $\begin{array}{l}\text { Temazepam-d5 } \\
\text { Estazolam-d5 }\end{array}$ & $\begin{array}{l}\text { B-glucuronidation } \\
\text { followed by dilute } \\
\text { and shoot }\end{array}$ & $\begin{array}{c}4 \\
2 \\
2.5 \\
1 \\
5 \\
2 \\
10 \\
2 \\
5 \\
2 \\
5\end{array}$ & $\begin{array}{c}10-1000 \\
2-200 \\
2.5-250 \\
1-100 \\
5-500 \\
5-500 \\
10-1000 \\
5-500 \\
5-500 \\
5-500 \\
5-500\end{array}$ & $\begin{array}{c}10 \\
2 \\
2.5 \\
1 \\
5 \\
5 \\
10 \\
5 \\
5 \\
5 \\
5\end{array}$ & [128] \\
\hline $\begin{array}{c}\text { Desmethylflunitrazepam } \\
\text { (fonazepam) }\end{array}$ & \multicolumn{8}{|c|}{ Numerous methods reviewed by Katselou [178] } \\
\hline Diclazepam & Plasma/urine & LC-MS & $\begin{array}{c}\text { Diazepam-d5 } \\
\text { Lorazepam-d4 } \\
\text { Nordazepam-d5 } \\
\text { Temazepam-d5 }\end{array}$ & $\begin{array}{l}\text { B-glucuronidation } \\
\text { then LLE using 1- } \\
\text { chlorobutane and } \\
\text { borate buffer (pH 9) }\end{array}$ & 0.25 & $0.25-100$ & Not provided & {$[81]$} \\
\hline
\end{tabular}

This article is protected by copyright. All rights reserved. 


\begin{tabular}{|c|c|c|c|c|c|c|c|c|}
\hline Etizolam & Plasma/Urine & HPLC & Alprazolam & LLE & 1 & $1-100$ & Not provided & {$[187]$} \\
\hline Etizolam & Plasma & HPLC & N/A & N/A & 0.3 & Not provided & $0.6 \mathrm{ng} / \mathrm{ml}$ & [93] \\
\hline Etizolam & Plasma/Urine & GC-MS/MS & Fludiazepam & SPE & Not provided & $5-50$ & Not provided & [188] \\
\hline Flubromazepam & Plasma/Urine & LC-MS/MS & Nordazepam & $\begin{array}{c}\text { LLE (1- } \\
\text { chlorobutane) }\end{array}$ & 1 & $1-100$ & Not provided & [79] \\
\hline Meclonazepam & Plasma & GC & None & LLE (butyl acetate) & 0.1 & $0.6-20$ & 0.6 & {$[142]$} \\
\hline Meclonazepam & Urine & LC-MS-QTOF & None & B-glucuronidation & Not provided & Not provided & Not provided & [186] \\
\hline Metizolam & Urine & LC-MS/MS & $\begin{array}{c}\text { Methyl-clonazepam \& } \\
\square-O H- \\
\text { ethylthoephyllin }\end{array}$ & $\begin{array}{c}\text { LLE } \\
\text { (dichloromethane/n- } \\
\text { heptane/isopropanol } \\
(25 / 65 / 20)\end{array}$ & 0.025 & $0.05-50$ & 0.05 & {$[177]$} \\
\hline Nifoxipam & \multicolumn{8}{|c|}{ Numerous methods reviewed by Katselou [178] } \\
\hline Nimetazepam & Urine & LC-MS/MS & Nitrazepam-d5 & SPE & 0.05 & $0.05-100$ & 0.1 & [189] \\
\hline Phenazepam & Plasma & GC & $\begin{array}{c}\text { 7-bromo-5-(2- } \\
\text { bromophenyl)-1,3- } \\
\text { dihydro-1,4- } \\
\text { benzodiazepin-2-one }\end{array}$ & LLE (diethyl ether) & $1-2$ & $1-150$ & Not provided & [190] \\
\hline Phenazepam & Plasma & GC-MS & Prazepam & SPE & Not provided & Not provided & 1 & {$[118]$} \\
\hline Phenazepam & Plasma/Plasma & LC-MS/MS & Diazepam & SPE & 1.44 & $5-1000$ & 3.06 & [24] \\
\hline Phenazepam & Plasma & Dual-column GC & Norclobazam & LLE (ethyl acetate) & $5 \mathrm{ng} \mathrm{g}^{-1}$ & $10-500 \mathrm{ng} \mathrm{g}^{-1}$ & $10 \mathrm{ng} \mathrm{g}^{-1}$ & {$[191]$} \\
\hline Phenazepam & Plasma & LC-MS/MS & Diazepam & LLE (acetone) & 12 & $100-1600$ & 28 & {$[25]$} \\
\hline Pyrazolam & Plasma/Urine & LC-MS/MS & Alprazolam & $\begin{array}{l}\text { LLE (1- } \\
\text { chlorobutane) }\end{array}$ & 1 & $1-100$ & Not provided & [126] \\
\hline
\end{tabular}

This article is protected by copyright. All rights reserved. 


\section{Table 8: Metabolic pathways and metabolites of NPS -benzodiazepines}

\begin{tabular}{|c|c|c|}
\hline Compound & Major Phase I metabolites (both in vivo and in vitro) & Reference(s) \\
\hline 3-hydroxyphenazepam & None Known & [184] \\
\hline 4-chlorodiazèpam (Ro5-4864) & $\begin{array}{c}\text { There appears to be a lack of information on the metabolic routes of this } \\
\text { benzodiazepine but they are possibly similar to those observed for } \\
\text { diclazepam such as N-demethylation and 3-hydroxylation }\end{array}$ & No reference \\
\hline Adinazolam & $\begin{array}{c}\text { N-desmethyladinazolam } \\
\mathrm{N}, \mathrm{N} \text {-didesmethyladinazolam } \\
\alpha \text {-hydroxyadinazolam, Estazolam }\end{array}$ & $\begin{array}{l}{[184]} \\
{[192]}\end{array}$ \\
\hline Bromazolam & $\begin{array}{l}\text { No experimental studies to date but possible metabolites are } \\
\text { hydroxylation at the } \alpha \text { or } 4 \text { positions as is the case with other } \\
\text { triazolobenzodiazepines }\end{array}$ & No reference \\
\hline Clonazolam & $\begin{array}{c}\text { 7-aminoclonazolam, 7-acetaminoclonazolam } \\
\text { Hydroxyclonazolam }\end{array}$ & {$[10,193]$} \\
\hline razepam & $\begin{array}{c}\text { Monohydroxylated cloniprazepam } \\
\text { Clonazepam (dealkylation) } \\
\text { Reduction of the 7-nitro to a 7-amino group } \\
\text { 7-aminoclonazepam (dealkylation and reduction) } \\
\text { Hydroxylation and dealkylation } \\
\text { Hydroxylation and dealkylation } \\
\text { Oxidation of the 3-hydroxy group to a 3-keto group }\end{array}$ & [184] \\
\hline lurazepam & $\begin{array}{l}\text { It is unclear as to whether this would go further phase I metabolism or } \\
\text { instead proceed directly to phase II metabolism as is the case when it is } \\
\text { a metabolite from flurazepam }\end{array}$ & [47] \\
\hline Deschloroetizolam & $\begin{array}{c}\text { Monohydroxylation (probable 9-methyl) } \\
\text { Monohydroxylation (probable 2-ethyl) } \\
\text { Monohydroxylation (probable position 6) } \\
\text { Dihydroxylation (positions undetermined) }\end{array}$ & {$[10,176]$} \\
\hline $\begin{array}{l}\text { Desmethylflunitrazepam } \\
\text { (fonazepam) }\end{array}$ & $\begin{array}{l}\text { 3-hydroxynorflunitrazepam } \\
\text { Monohydroxylation (position undetermined) } \\
\text { 7-aminonorflunitrazepam }\end{array}$ & [184] \\
\hline Diclazepam & $\begin{array}{l}\text { Delorazepam, Lorazepam } \\
\text { Lormetazepam }\end{array}$ & {$[81,176]$} \\
\hline zolam & $\begin{array}{l}\text { Hydroxylation on the } \alpha \text {-carbon of the 9-methyl group } \\
\text { (also known as } \alpha \text {-hydroxyetizolam) } \\
\text { Hydroxylation on the } \alpha \text {-carbon of the 2-ethyl group } \\
\text { (also known as 8-hydroxyetizolam) }\end{array}$ & {$[176,187]$} \\
\hline nazepam & $\begin{array}{c}\text { Monohydroxylation (possibly 3-hydroxy, undetermined) } \\
\text { Debromination and monohydroxylation (possibly 3-hydroxy, } \\
\text { undetermined) } \\
\text { Monohydroxylation (either on the phenyl ring or the benzene ring, } \\
\text { undetermined) }\end{array}$ & {$[79,176]$} \\
\hline Flubromazolam & $\begin{array}{l}\text { a-hydroxyflubromazepam } \\
\text { 4-hydroxyflubromazepam } \\
\text { Dihydroxylation }(\alpha \text {-hydroxy and 4-hydroxy })\end{array}$ & {$[10,176]$} \\
\hline razolam & $\begin{array}{l}\text { No experimental studies to date but possible metabolites are reduction of } \\
\text { the 8-nitro group to a 8-amino group and hydroxylation at position } 4 \text { of } \\
\text { the diazepine ring. }\end{array}$ & No reference \\
\hline Flutazolam & $\begin{array}{c}\text { Oxazole ring-opening and elimination } \\
\text { The above metabolite is thought to be the main metabolite present in } \\
\text { plasma but other metabolic pathways do exist: } \\
\text { N1-dealkylation (loss of } \mathrm{CH}_{2} \mathrm{CH}_{2} \mathrm{OH} \text { ), 3-hydroxylation } \\
\text { Hydroxylation on either the fluorophenyl or chlorophenyl ring } \\
\text { Both N1-dealkylation and 3-hydroxylation }\end{array}$ & [36] \\
\hline Meclonazepam & 7-aminomeclonazepam, 7-acetaminomeclonazepam & {$[176,193]$} \\
\hline Metizolam & $\begin{array}{l}\text { 2 mono-hydroxylated compounds } \\
\text { Di-hydroxylated compound } \\
\text { Hydroxylation (likely to be 2-ethyl or 6- position) } \\
\end{array}$ & {$[177,184]$} \\
\hline Nifoxipam & 7-aminonifoxipam, 7-acetaminonifoxipam & {$[176,193]$} \\
\hline Nimetazepam & Nitrazepam, 7-aminonimetazepam & [189] \\
\hline Nitrazolam & 8-aminonitrazolam & [184] \\
\hline
\end{tabular}




\begin{tabular}{|c|c|c|}
\hline & Mono hydroxylated metabolite (likely either 4- or $\alpha$ - position) & 3-hydroxyphenazepam \\
\hline Phenazepam & Hydroxylation and methoxy addition (positions undetermined) & {$[18,101]$} \\
\hline Pyrazolam & No detectable metabolites in serum or urine & {$[126]$} \\
\hline
\end{tabular}
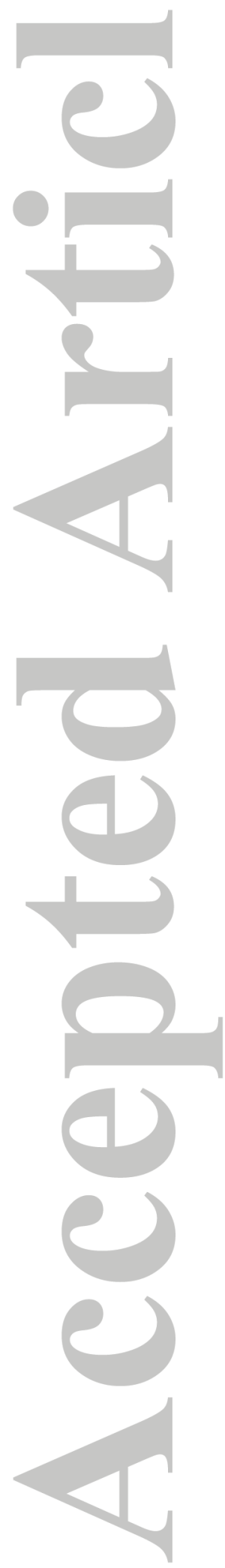


\section{REFERENCES}

1. United Nations Office on Drugs and Crime (UNODC), World Drug Report, 2016, New York, U.S.A. [cited 2017 March]; Available from:

https://www.unodc.org/documents/colombia/2016/WDR/WORLD_DRUG_REPORT_2016_w eb.pdf.

2. European Monitoring Centre for Drugs and Drug Addiction (EMCDDA)-Europol, European Drug Report: Trends and Developments, 2015, Lisbon, Portugal [cited 2017 March]; Available from: http://www.emcdda.europa.eu/attachements.cfm/att_239505_EN_TDAT15001ENN.pdf

3. EMCDDA-Europol, European Drug Report: Trends and Developments, 2016, Lisbon, Portugal [cited 2017 March]; Available from:

http://www.emcdda.europa.eu/system/files/publications/2637/TDAT16001ENN.pdf

4. UNODC, The International Drug Control Conventions, Schedules of the Convention on Psychotropic Substances of 1971 as at 4 November 2015, 2015.

$5 . \quad$ M.A. Bachhuber, S. Hennessy, C.O. Cunningham,J.L. Starrels, Increasing Benzodiazepine Prescriptions and Overdose Mortality in the United States 1996-2013. American Journal of Public Health, 2016, 106, 686-688.

6. Health and Social Care Information Centre, Prescriptions Dispensed in the Community, Statistics for England - 2004-2014. 2015.

7. J.D. Jones, S. Mogali,S.D. Comer, Polydrug Abuse: A Review of Opioid and Benzodiazepine Combination Use. Drug and Alcohol Dependence, 2012, 125, 8-18.

8. V. Kapil, J.L. Green, C.L. Lait, D.M. Wood,P.I. Dargan, Misuse of Benzodiazepines and Z-Drugs in the Uk. British Journal of Psychiatry, 2014, 205, 407-408.

9. M. Vogel, B. Knöpfli, O. Schmid, M. Prica, J. Strasser, L. Prieto, G.A. Wiesbeck,K.M. DürstelerMacfarland, Treatment or "High": Benzodiazepine Use in Patients on Injectable Heroin or Oral Opioids. Addictive Behaviours, 2013, 38, 2477-2484.

10. L. Huppertz, P. Bisel, F. Westphal, F. Franz, V. Auwärter,B. Moosmann, Characterization of the Four Designer Benzodiazepines Clonazolam, Deschloroetizolam, Flubromazolam, and Meclonazepam, and Identification of Their in Vitro Metabolites. Forensic Toxicology, 2015, 33, 388-395.

11. RAND Corporation. [cited 2016 August]; Available from: http://www.rand.org/pubs/research_reports/RR1607.html.

12. UNODC, The Challenge of New Psychoactive Substances, 2013, Vienna, Austria, [cited 2017 March]; Available from: https://www.unodc.org/documents/scientific/NPS_2013_SMART.pdf

13. Reddit. [cited 2017 March]; Available from: www.reddit.com.

14. Bluelight. [cited 2017 March]; Available from: www.bluelight.org.

15. Flashback. [cited 2017 March]; Available from: https://www.flashback.org/t2805464.

16. UK Chemical Research. [cited 2017 March]; Available from: https://www.ukchemicalresearch.org/Thread-N-Desalkylflurazepam-Norflurazepam.

17. EMCDDA, Emcdda-Europol 2007 Annual Report on the Implementation of Council Decision 2005/387/JHA, 2007, Lisbon, Portgual, [cited 2017 March]; Available from:

http://www.emcdda.europa.eu/system/files/publications/503/2007_Implementation_repor t_281403.pdf

18. V.P. Zherdev, S. Caccia, S. Garattini,A.L. Ekonomov, Species Differences in Phenazepam Kinetics and Metabolism. European Journal of Drug Metabolism and Pharmacokinetics, 1982, 7, 191-196.

19. Чекулаев Матвей Игоревич, Максимова Татьяна Владимировна, Барсегян Самвел Сережаевич, ОПАСНОСТЬ ФЕНАЗЕПАМА КАК УЛИЧНОГО НАРКОТИКА. Здоровье и образование в XXI веке, 2015, 17, 85-86.

This article is protected by copyright. All rights reserved. 
20. B.-L. Zhu, L. Meng,K.-f. Zheng, Analysis of the New Psychoactive Substance of Phenazepam. Chinese Journal of Forensic Sciences, 2014, 6, 44.

21. A. McAuleya, G. Hecht, L. Barnsdale, C.S. Thomson, L. Graham, S. Priyadarshi,J.R. Robertson, Mortality Related to Novel Psychoactive Substances in Scotland, 2012: An Exploratory Study. International Journal of Drug Policy, 2015, 26, 461-467.

22. K. Shearer, C. Bryce, M. Parsons,H. Torrance, Phenazepam: A Review of Medico-Legal Deaths in South Scotland between 2010 and 2014. Forensic Science International, 2015, 254, 197204.

23. K.W. Simonsen, H.M.E. Edvardsen, G. Thelander, I. Ojanpera, S. Thordardottir, L.V. Andersen, P. Kriikku, V. Vindenes, D. Christoffersen, G.J.M. Delaveris,J. Frost, Fatal Poisoning in Drug Addicts in the Nordic Countries in 2012. Forensic Science International, 2015, 248, 172-180.

24. P. Kriikku, L. Wilhelm, J. Rintatalo, J. Hurme, J. Kramer,I. Ojanperä, Phenazepam Abuse in Finland: Findings from Apprehended Drivers, Post-Mortem Cases and Police Confiscations. Forensic Science International, 2012, 10, 1-3.

25. J.B. Stephenson, D.E. Golz,M.J. Brasher, Phenazepam and Its Effects on Driving. Journal of Analytical Toxicology, 2013, 37, 25-29.

26. Government of Finland. [cited 2016 June]; Available from: http://www.finlex.fi/fi/laki/alkup/2014/20140589.

27. Government of China. [cited 2016 June]; Available from: http://www.sfda.gov.cn/WS01/CL0056/130753.html.

28. U.K. Government. [cited 2015 October]; Available from: www.gov.uk/government/news/import-ban-of-new-legal-high-phenazepam-introduced.

29. UN Commission on Narcotic Drugs, Inclusion of Phenazepam in Schedule Iv of the Convention on Psychotropic Substances of 1971. 2016.

30. EMCDDA-Europol, Emcdda-Europol 2011 Annual Report on the Implementation of Council Decision 2005/387/JHA, 2011, Lisbon, Portugal, [cited 2017 March]; Available from: http://www.emcdda.europa.eu/system/files/publications/689/EMCDDA-

Europol_Annual_Report_2011_2012_final_335568.pdf

31. Mitsubishi-Tanabe-Pharma-Corporation. [cited 2015 October]; Available from: http://medical.mt-pharma.co.jp/di/file/if/f_dep.pdf.

32. EMCDDA-Europol, Emcdda-Europol 2012 Annual Report on the Implementation of Council Decision 2005/387/JHA, 2012, Lisbon, Portugal, [cited 2017 March]; Available from: http://www.emcdda.europa.eu/system/files/publications/734/EMCDDAEuropol_2012_Annual_Report_final_439477.pdf

33. EMCDDA-Europol, Emcdda-Europol 2013 Annual Report on the Implementation of Council Decision 2005/387/JHA, 2013, Lisbon, Portugal, [cited 2017 March]; Available from:

http://www.emcdda.europa.eu/system/files/publications/814/TDAN14001ENN_475519.pdf

34. EMCDDA-Europol, Emcdda-Europol 2014 Annual Report on the Implementation of Council Decision 2005/387/JHA, 2014, Lisbon, Portugal, [cited 2017 March]; Available from: http://www.emcdda.europa.eu/system/files/publications/1018/TDAN15001ENN.pdf

35. EMCDDA-Europol, Emcdda-Europol 2015 Annual Report on the Implementation of Council Decision 2005/387/JHA, 2016, Lisbon, Portugal, [cited 2017 March]; Available from: http://www.emcdda.europa.eu/system/files/publications/1018/TDAN15001ENN.pdf

36. Mitsubishi-Tanabe-Pharma-Corporation. [cited 2015 November]; Available from: http://medical.mt-pharma.co.jp/di/file/if/f_crm.pdf.

37. Medical Products Agency Sweden. [cited 2016 February]; Available from: https://lakemedelsverket.se/overgripande/Lagar--regler/Yttranden-enligt-lagen-omforstorande-av-vissa-halsofarliga-missbrukssubstanser/.

38. Medical Products Agency Sweden. [cited 2016 September]; Available from: https://www.folkhalsomyndigheten.se/documents/tillsyn-regelverk/klassificeringmissbrukssubstanser/substanser/n-desmetylflunitrazepam.pdf. 
39. Austrian Public Health Institute. [cited 2017 March]; Available from: https://forum.goeg.at/EwsForum/default.aspx?g=posts\&m=270.

40. National Forensic Laboratory Slovenia. [cited 2017 March]; Available from: http://www.policija.si/apps/nfl_response_web/0_Analytical_Reports_final/Ro54864_(Chlorodiazepam)-ID-1567-16_rpt-110816.pdf.

41. Office for National Statistics. [cited 2016 February]; Available from: http://www.ons.gov.uk/ons/rel/subnational-health3/deaths-related-to-drugpoisoning/england-and-wales---2014/index.html.

42. U.K. Government. [cited 2015 November]; Available from: https://www.gov.uk/government/collections/psychoactive-substances-bill-2015.

43. U.K. Government, Misuse of Drugs Act, 1971.

44. O.H. Drummer, The Forensic Pharmacology of Drugs of Abuse. 2001, Great Britain: Arnold.

45. M.T. Smith, L.E.J. Evans, M.J. Eadie,J.H. Tyre, Pharmacokinetics of Prazepam in Man European Journal of Clinical Pharmacology, 1979, 16, 141-147.

46. M. Mandelli, G. Tognoni,S. Garattini, Clinical Pharmacokinetics of Diazepam. Clinical Pharmacokinetics, 1978, 3, 72-91.

47. D.D. Breimer,R. Jochemsen, Clinical Pharmacokinetics of Hypnotic Benzodiazepines. British Journal of Clinical Pharmacology, 1983, 16, 277S-278S.

48. H.J. Gerhards, Neuropharmacological Profile of Clobazam, a New 1',5'-Benzodiazepine. Psychopharmacology, 1978, 58, 27-33.

49. D.J. Greenblatt, L.L.v. Moltke, J.S. Harmatz, D.A. Ciraulo,R.I. Shader, Alprazolam Pharmacokinetics, Metabolism, and Plasma Levels: Clinical Implications. Journal of Clinical Psychiatry, 1993, 54, 4-14.

50. M.T. Smith, M.J. Eadie,T.O.R. Brophy, The Pharmacokinetics of Midazolam in Man. European Journal of Clinical Pharmacology, 1981, 19, 271-278.

51. K.A. Fischer-Cornelssen, Multicenter Trials and Complementary Studies of Cloxazolam, a New Anxiolytic Drug. Arzneimittelforschung, 1981, 31, 1757-1765.

52. A. Bertolino, E. Mastucci, V. Porro, L. Corfiati, M. Palermo, U. Ecarf,G. Ceccarelli, Etizolam in the Treatment of Generalized Anxiety Disorder: A Controlled Clinical Trial. The Journal of International Medical Research, 1989, 17, 455-460.

53. M. Casacchiaa, F. Bolinoa,U. Ecarib, Etizolam in the Treatment of Generalized Anxiety Disorder: A Double-Blind Study Versus Placebo. Current Medical Research and Opinion, 1990, $12,215-223$.

54. M.S. Langley,S.P. Clissold, Brotizolam. A Review of Its Pharmacodynamic and Pharmacokinetic Properties, and Therapeutic Efficacy as an Hypnotic. Drugs, 1988, 35, $104-$ 122.

55. C. Rundfeldt, K. Socała,P. Wlaź, The Atypical Anxiolytic Drug, Tofisopam, Selectively Blocks Phosphodiesterase Isoenzymes and Is Active in the Mouse Model of Negative Symptoms of Psychosis. Journal of Neural Transmission, 2010, 117, 1319-1325.

56. R. Gitto, M. Zappalà, G.D. Sarro,A. Chimirri, Design and Development of 2,3-Benzodiazepine (Cfm) Noncompetitive Ampa Receptor Antagonists. II Farmaco, 2002, 57, 129-134.

57. E.J. Horváth, K. Horváth, T. Hámori, M.I. Fekete, S. Sólyom,M. Palkovits, Anxiolytic 2,3Benzodiazepines, Their Specific Binding to the Basal Ganglia. Progress in Neurobiology, 2000, 60, 309-342.

58. British Journal of Clinical Pharmacology, Gabaa (Г-Aminobutyric Acid). British Journal of Clinical Pharmacology, 2009, 158(Suppl 1), S110-S112.

59. R.W. Olsen,W. Sieghart, International Union of Pharmacology. Lxx. Subtypes of GammaAminobutyric Acid(a) Receptors: Classification on the Basis of Subunit Composition, Pharmacology, and Function. Update. Pharmacological Reviews, 2008, 60, 243-260.

60. R.W. Olsen,W. Sieghart, Gaba a Receptors: Subtypes Provide Diversity of Function and Pharmacology. Neuropharmacology, 2009, 56, 141-148. 
61. W. Sieghart,G. Sperk, Subunit Composition, Distribution and Function of Gaba(a) Receptor Subtypes. Current Topics in Medicinal Chemistry, 2002, 2, 795-816.

62. K.R. Tan, U. Rudolph,C. Lüscher, Hooked on Benzodiazepines: Gabaa Receptor Subtypes and Addiction. Trends in Neurosciences, 2011, 34, 188-197.

63. A.E. Heikkinen, T.P. Möykkynen,E.R. Korpi, Long-Lasting Modulation of Glutamatergic Transmission in Vta Dopamine Neurons after a Single Dose of Benzodiazepine Agonists. Neuropsychopharmacology, 2009, 34, 290-298.

64. K.R. Tan, M. Brown, G. Labouèbe, C. Yvon, C. Creton, J.M. Fritschy, U. Rudolph, C. Lüscher, Neural Bases for Addictive Properties of Benzodiazepines. Nature, 2010, 463, 769-774.

65. E. Sigel,M.E. Steinmann, Structure, Function, and Modulation of Gabaa Receptors. Journal of Biological Chemistry, 2012, 287, 40224-40231.

66. A.C. Grobin, D.B. Matthews, L.L. Devaud,A.L. Morrow, The Role of Gabaa Receptors in the Acute and Chronic Effects of Ethanol. Psychopharmacology, 1998, 139, 2-19.

67. R.W. Olsen, Gaba-Benzodiazepine-Barbiturate Receptor Interactions. Journal of Neurochemistry, 1981, 37, 1-13.

68. P.V. Holmes, R.C. Drugan, Differential Effects of Anxiogenic Central and Peripheral Benzodiazepine Receptor Ligands in Tests of Learning and Memory. Psychopharmacology, 1991, 104, 249-254.

69. V. Papadopoulos, M. Baraldi, T.R. Guilarte, T.B. Knudsen, J.J. Lacapère, P. Lindemann, M.D. Norenberg, D. Nutt, A. Weizman, M.R. Zhang,M. Gavish, Translocator Protein (18 Kda): New Nomenclature for the Peripheral-Type Benzodiazepine Receptor Based on Its Structure and Molecular Function. Trends in Pharmacological Sciences, 2006, 27, 402-409.

70. P. Casellas, S. Galiegue,A.S. Basile, Peripheral Benzodiazepine Receptors and Mitochondrial Function. Neurochemistry International, 2002, 40, 475-486.

71. M. Gavish, I. Bachman, R. Shoukrun, Y. Katz, L. Veenman, G. Weisinger,A. Weizman, Enigma of the Peripheral Benzodiazepine Receptor. Pharmacological Reviews, 1999, 51, 629-650.

72. R. Rupprecht, V. Papadopoulos, G. Rammes, T.C. Baghai, J. Fan, N. Akula, G. Groyer, D. Adams,M. Schumacher, Translocator Protein (18 Kda) (Tspo) as a Therapeutic Target for Neurological and Psychiatric Disorders. Nature Reviews Drug Discovery, 2010, 9, 971-988.

73. V. Papadopoulos,L. Lecanu, Translocator Protein (18 Kda) Tspo: An Emerging Therapeutic Target in Neurotrauma. Experimental Neurology, 2009, 219, 53-57.

74. R. Rupprecht, G. Rammes, D. Eser, T.C. Baghai, C. Schüle, C. Nothdurfter, T. Troxler, C. Gentsch, H.O. Kalkman, F. Chaperon, V. Uzunov, K.H. McAllister, V. Bertaina-Anglade, C D La Rochelle, D. Tuerck, A. Floesser, B. Kiese, M. Schumacher, R. Landgraf, F. Holsboer, K. Kucher, Translocator Protein (18 Kd) as Target for Anxiolytics without Benzodiazepine-Like Side Effects. Science, 2009, 325, 490-493.

75. S. Pellow,S.E. File, Anxiolytic and Anxiogenic Drug Effects on Exploratory Activity in an Elevated Plus-Maze: A Novel Test of Anxiety in the Rat. Pharmacology, Biochemistry and Behaviour, 1986, 24, 525-529.

76. S.E. File, A.R. Green, D.J. Nutt,N.D. Vincent, On the Convulsant Action of Ro 5-4864 and the Existence of a Micromolar Benzodiazepine Binding Site in Rat Brain. Psychopharmacology, 1984, 82, 199-202.

77. M. Gavish, Y. Katz, S. Bar-Ami, R. Weizman, Biochemical, Physiological, and Pathological Aspects of the Peripheral Benzodiazepine Receptor. Journal of Neurochemistry, 1991, 58, 1589-1601.

78. E.C. Lomas,P.D. Maskell, Phenazepam: More Information Coming in from the Cold. J Forensic Leg Med, 2015, 36, 61-62.

79. B. Moosmann, L. Huppertz, M. Hutter, A. Buchwald, S. Ferlaino,V. Auwärter, Detection and Identification of the Designer Benzodiazepine Flubromazepam and Preliminary Data on Its Metabolism and Pharmacokinetics. Journal of Mass Spectrometry, 2013, 48, 1150-1159. 
80. R.B. Smith, P.D. Kroboth,J.P. Phillips, Temporal Variation in Triazolam Pharmacokinetics and Pharmacodynamics after Oral Administration. Journal of Clinical Pharmacology, 1986, 26, 120-124.

81. B. Moosmann, P. Bisel,V. Auwärter, Characterization of the Designer Benzodiazepine Diclazepam and Preliminary Data on Its Metabolism and Pharmacokinetics. Drug Testing and Analysis, 2014, 6, 757-763.

82. P.D. Kroboth, J.W. McAuley, F.J. Kroboth, R.J. Bertz,R.B. Smith, Triazolam Pharmacokinetics after Intravenous, Oral, and Sublingual Administration. Journal of Clinical Psychopharmacology, 1995, 15, 259-262.

83. H.R. Ochs, H. Otten, D.J. Greenblatt,H.J. Dengler, Diazepam Absorption: Effects of Age, Sex, and Billroth Gastrectomy. Digestive Diseases and Sciences, 1982, 27, 225-230.

84. U. Klotz, K.H. Antonin,P.R. Bieck, Pharmacokinetics and Plasma Binding of Diazepam in Man, Dog, Rabbit, Guinea Pig and Rat. The Journal of Pharmacology and Experimental Therapeutics, 1976, 199, 67-73.

85. P.D. Garzone,P.D. Kroboth, Pharmacokinetics of the Newer Benzodiazepines. Clinical Pharmacokinetics, 1989, 16, 337-364.

86. J. Sonne, S. Loft, M. Døssing, A. Vollmer-Larsen, K.L. Olesen, M. Victor, F. Andreasen,P.B. Andreasen, Bioavailability and Pharmacokinetics of Oxazepam. European Journal of Clinical Pharmacology, 1988, 35, 385-389.

87. H.G. Boxenbaum, H.N. Posmanter, T. Macasieb, K.A. Geitner, R.E. Weinfeld, J.D. Moore, A. Darragh, D.A. O'Kelly, L. Weissman,S.A. Kaplan, Pharmacokinetics of Flunitrazepam Following Single- and Multiple-Dose Oral Administration to Healthy Human Subjects Journal of Pharmacokinetics and Biopharmaceutics, 1978, 6, 283-293.

88. C. Xu, C.Y.-T. Li,A.-N.T. Kong, Induction of Phase I, li and lii Drug Metabolism/Transport by Xenobiotics Archives of Pharmacal Research, 2005, 28, 249-268.

89. K. Mizuno, M. Katoh, H. Okumura, N. Nakagawa, T. Negishi, T. Hashizume, M. Nakajima,T. Yokoi, Metabolic Activation of Benzodiazepines by Cyp3a4. Drug Metabolism and Disposition, 2009, 37, 345-351.

90. T. Fukasawa, A. Suzuki,K. Otani, Effects of Genetic Polymorphism of Cytochrome P450 Enzymes on the Pharmacokinetics of Benzodiazepines. Journal of Clinical Pharmacy and Therapeutics, 2007, 32, 333-341.

91. M. Whirl-Carrillo, E.M. McDonagh, J.M. Hebert, L. Gong, K. Sangkuhl, C.F. Thorn, R.B. Altman,T.E. Klein, Pharmacogenomics Knowledge for Personalized Medicine. Clinical Pharmacology and Therapeutics, 2012, 92, 414-417.

92. A. Parmeggiani, A. Posar, S. Sangiorgi,P. Giovanardi-Rossi, Unusual Side-Effects Due to Clobazam: A Case Report with Genetic Study of Cyp2c19. Brain \& Development, 2004, 26, 6366.

93. T. Fukasawa, N. Yasui-Furukori, A. Suzuki, Y. Inoue, T. Tateishi,K. Otani, Pharmacokinetics and Pharmacodynamics of Etizolam Are Influenced by Polymorphic Cyp2c19 Activity. European Journal of Clinical Pharmacology, 2005, 61, 791-795.

94. D.R. Sohn, M. Kusaka, T. Ishizaki, S.G. Shin, I.J. Jang, J.G. Shin,K. Chiba, Incidence of SMephenytoin Hydroxylation Deficiency in a Korean Population and the Interphenotypic Differences in Diazepam Pharmacokinetics. Clinical Pharmacology and Therapeutics, 1992, 52, 160-169.

95. J.A. Goldstein, Clinical Relevance of Genetic Polymorphisms in the Human Cyp2c Subfamily. British Journal of Clinical Pharmacology, 2001, 52, 349-355.

96. L. Bertilsson, T.K. Henthorn, E. Sanz, G. Tybring, J. Säwe,T. Villén, Importance of Genetic Factors in the Regulation of Diazepam Metabolism: Relationship to S-Mephenytoin, but Not Debrisoquin, Hydroxylation Phenotype. Clinical Pharmacology and Therapeutics, 1989, 45, 348-355. 
97. M.H. Court, Q. Hao, S. Krishnaswamy, T. Bekaii-Saab, A. Al-Rohaimi, L L von Moltke,D.J. Greenblatt, Udp-Glucuronosyltransferase (Ugt) 2 b15 Pharmacogenetics: Ugt2b15 D85y Genotype and Gender Are Major Determinants of Oxazepam Glucuronidation by Human Liver. Journal of Pharmacology and Experimental Therapeutics, 2004, 310, 656-665.

98. M.H. Court, S.X. Duan, C. Guillemette, K. Journault, S. Krishnaswamy, L.L. Von-Moltke,D.J. Greenblatt, Stereoselective Conjugation of Oxazepam by Human UdpGlucuronosyltransferases (Ugts): S-Oxazepam Is Glucuronidated by Ugt2b15, While ROxazepam Is Glucuronidated by Ugt2b7 and Ugt1a9. Drug Metabolism and Disposition, 2002, 30, 1257-1265.

99. K. Bourcier, R. Hyland, S. Kempshall, R. Jones, J. Maximilien, N. Irvine,B. Jones, Investigation into Udp-Glucuronosyltransferase (Ugt) Enzyme Kinetics of Imidazole- and TriazoleContaining Antifungal Drugs in Human Liver Microsomes and Recombinant Ugt Enzymes. Drug Metabolism and Disposition, 2010, 38, 923-929.

100. M. Olivera, C. Martínez, G. Gervasini, J.A. Carrillo, S. Ramos, J. Benítez, E. García-Martin,J.A. Agúndez, Effect of Common Nat2 Variant Alleles in the Acetylation of the Major Clonazepam Metabolite, 7-Aminoclonazepam. Drug Metabolism Letters, 2007, 1, 3-5.

101. P.D. Maskell, G. De-Paoli, L.N. Seetohul,D.J. Pounder, Phenazepam: The Drug That Came in from the Cold. Journal of Forensic and Legal Medicine, 2012, 19, 122-125.

102. M.P. Peppers, Benzodiazepines for Alcohol Withdrawal in the Elderly and in Patients with Liver Disease. Pharmacotherapy, 1996, 16, 49-57.

103. A. Mozayani,L. Raymon, Handbook of Drug Interactions: A Clinical and Forensic Guide. 2003, New York: Springer Science \& Business Media.

104. A.D. Fraser, W. Bryan,A.F. Isner, Urinary Screening for Alprazolam and Its Major Metabolites by the Abbott Adx and Tdx Analyzers with Confirmation by Gc/Ms. Journal of Analytical Toxicology, 1991, 15, 25-29.

105. T. Inoue,T. Niwaguchi, Determination of Nitrazepam and Its Main Metabolites in Urine by Thin-Layer Chromatography and Direct Densitometry. Journal of Chromatography, 1985, 339, 163-169.

106. M.V. Kopanitsa, O.V. Zhuk, V.G. Zinkovsky,O.A. Krishtal, Modulation of Gaba $a_{a}$ ReceptorMediated Currents by Phenazepam and Its Metabolites. Naunyn-Schmiedeberg's Archives of Pharmacology, 2001, 364, 1-8.

107. M.N. Uddin, S. Victoria F,I.N. Papadoyannis, An Overview on Total Analytical Methods for the Detection of 1,4-Benzodiazepines. Pharmaceutica Analytica Acta, 2014, 5, 1-13.

108. K. Persona, K. Madej, P. Knihnicki,W. Piekoszewski, Analytical Methodologies for the Determination of Benzodiazepines in Biological Samples. Journal of Pharmaceutical and Biomedical Analysis, 2015, 113, 239-264.

109. A.C. Moffat, M.D. Osselton, B. Widdop,J. Watts, Clarke's Analysis of Drugs and Poisons. Fourth ed. 2011, London, U.K.,: Pharmaceutical Press.

110. M.D. Krasowski, A.F. Pizon, M.G. Siam, S. Giannoutsos, M. Iyer,S. Ekins, Using Molecular Similarity to Highlight the Challenges of Routine Immunoassay-Based Drug of Abuse/Toxicology Screening in Emergency Medicine. BMC Emergency Medicine, 2009, 9, 5.

111. L.C. O'Connor, H.J. Torrance,D.A. McKeown, Elisa Detection of Phenazepam, Etizolam, Pyrazolam, Flubromazepam, Diclazepam and Delorazepam in Blood Using Immunalysis ${ }^{\circledR}$ Benzodiazepine Kit. Journal of Analytical Toxicology, 2016, 40, 159-161.

112. M. Pettersson Bergstrand, A. Helander, T. Hansson, O. Beck, Detectability of Designer Benzodiazepines in Cedia, Emit li Plus, Heia, and Kims li Immunochemical Screening Assays. Drug Testing and Analysis, 2016.

113. S. Pellow,S.E. File, Behavioural Actions of Ro 5-4864: A Peripheral-Type Benzodiazepine? Life Sciences, 1984, 35, 229-240. 
114. M. Pettersson Bergstrand, A. Helander,O. Beck, Development and Application of a MultiComponent LC-Ms/Ms Method for Determination of Designer Benzodiazepines in Urine. Journal of Chromatography B, 2016, 1035, 104-110.

115. W.E. Lambert, E. Meyer, Y. Xue-Ping,A.P.D. Leenheer, Screening, Identification, and Quantitation of Benzodiazepines in Postmortem Samples by Hplc with Photodiode Array Detection. Journal of Analytical Toxicology, 1995, 19, 35-40.

116. K.K. Akerman, J. Jolkkonen, M. Parviainen,I. Penttilä, Analysis of Low-Dose Benzodiazepines by Hplc with Automated Solid-Phase Extraction. Clinical Chemistry, 1996, 42, 1412-1416.

117. M. Yegles, F. Mersch,R. Wennig, Detection of Benzodiazepines and Other Psychotropic Drugs in Human Hair by Gc/Ms. Forensic Science International, 1997, 84, 211-218.

118. S. Kerrigan, M.B. Mellon,P. Hinners, Detection of Phenazepam in Impaired Driving. Journal of Analytical Toxicology, 2013, 37, 605-610.

119. S. McClean, E. O'Kane, J. Hillis,W.F. Smyth, Determination of 1,4-Benzodiazepines and Their Metabolites by Capillary Electrophoresis and High-Performance Liquid Chromatography Using Ultraviolet and Electrospray Ionisation Mass Spectrometry. Journal of Chromatography A, 1999, 838, 273-291.

120. M. Roman, L. Strom, H. Tell,M. Josefsson, Liquid Chromatography/Time-of-Flight Mass Spectrometry Analysis of Postmortem Blood Samples for Targeted Toxicological Screening. Analytical and bioanalytical chemistry, 2013, 405, 4107-4125.

121. T. Soriano, C. Jurado, M. Menendez,M. Repetto, Improved Solid-Phase Extraction Method for Systematic Toxicological Analysis in Biological Fluids. Journal of Analytical Toxicology, 2001, 25, 137-143.

122. L. Anzillotti, S. Odoardi,S. Strano-Rossi, Cleaning up Blood Samples Using a Modified "Quechers" Procedure for the Determination of Drugs of Abuse and Benzodiazepines by Uplc-Msms. Forensic Science International, 2014, 243, 99-106.

123. K. Usui, Y. Hayashizaki, M. Hashiyada,M. Funayama, Rapid Drug Extraction from Human Whole Blood Using a Modified Quechers Extraction Method. Legal Medicine, 2012, 14, 286296.

124. J.L. Westland,F.L. Dorman, Quechers Extraction of Benzodiazepines in Biological Matrices Journal of Pharmaceutical Analysis, 2013, 3, 509-517.

125. G. Famiglini, F. Capriotti, P. Palma, V. Termopoli,A. Cappiello, The Rapid Measurement of Benzodiazepines in a Milk-Based Alcoholic Beverage Using Quechers Extraction and Gc-Ms Analysis. Journal of Analytical Toxicology, 2015, 39, 306-312.

126. B. Moosmann, M. Hutter, L M Huppertz, S. Ferlaino, L. Redlingshöfer, V. Auwärter, Characterization of the Designer Benzodiazepine Pyrazolam and Its Detectability in Human Serum and Urine. Forensic Toxicology, 2013, 31, 263-271.

127. L.C. O'Connor, H.J. Torrance,D.A. McKeown, Elisa Detection of Phenazepam, Etizolam, Pyrazolam, Flubromazepam, Diclazepam and Delorazepam in Blood Using Immunalysisw Benzodiazepine Kit. Journal of Analytical Toxicology, 2016, 40, 159-161.

128. M.P. Bergstrand, A. Helander,O. Beck, Development and Application of a Multi-Component LC-Ms/Ms Method for Determination of Designer Benzodiazepines in Urine. Journal of Chromatography B, 2016, 1035, 104-110.

129. S El Balkhi, M. Chaslot, N. Picard, S. Dulaurent, M. Delage, O. Mathieu,F. Saint-Marcoux, Characterization and Identification of Eight Designer Benzodiazepine Metabolites by Incubation with Human Liver Microsomes and Analysis by a Triple Quadrupole Mass Spectrometer. International journal of legal medicine, 2017.

130. O.V. Zhuk, V.G. Zinkovsky, S.I. Schukin,A.V. Sivachenko, Biotransformation, Pharmacokinetics and Pharmacodynamics of Cinazepam. Pharmacological Reports, 2007, 59, 60-61.

131. M.A. Schwartz,E. Postma, Metabolism of Flurazepam, a Benzodiazepine, in Man and Dog. Journal of Pharmaceutical Sciences, 1970, 59, 1800-1806. 
132. P. Heizmann, M. Eckert,W.H. Ziegler, Pharmacokinetics and Bioavailability of Midazolam in Man. British Journal of Clinical Pharmacology, 1983, 16, 43S-49S.

133. N. Barzaghi, L. Leone, M. Monteleone, G. Tomasini,E. Perucca, Pharmacokinetics of Flutoprazepam, a Novel Benzodiazepine Drug, in Normal Subjects. European Journal of Drug Metabolism and Pharmacokinetics, 1989, 14, 293-298.

134. I. Nakatsuka, H. Shimizu, Y. Asami, T. Katoh, A. Hirose,A. Yoshitake, Benzodiazepines and Their Metabolites: Relationship between Binding Affinity to the Benzodiazepine Receptor and Pharmacological Activity. Life Sciences, 1985, 36, 113-119.

135. G. Skopp, Preanalytic Aspects in Postmortem Toxicology. Forensic Science International, 2004, 142, 75-100.

136. M.D. Robertson,O.H. Drummer, Stability of Nitrobenzodiazepines in Postmortem Blood. Journal of Forensic Sciences, 1998, 43, 5-8.

137. A. El Mahjoub,C. Staub, Stability of Benzodiazepines in Whole Blood Samples Stored at Varying Temperatures. Journal of Pharmaceutical and Biomedical Analysis, 2000, 23, 10571063.

138. G. Skopp, L. Potsch, I. Konig, R. Mattern, A Preliminary Study on the Stability of Benzodiazepines in Blood and Plasma Stored at 4 Degrees $C$. International journal of legal medicine, 1998, 111, 1-5.

139. P. Melo, M.L. Bastos,H.M. Teixeira, Benzodiazepine Stability in Postmortem Samples Stored at Different Temperatures. Journal of Analytical Toxicology, 2012, 36, 52-60.

140. B. Levine, R.V. Blanke,J.C. Valentour, Postmortem Stability of Benzodiazepines in Blood and Tissues. Journal of Forensic Sciences, 1983, 28, 102-115.

141. S.S. Kirsty H Watson, Lauren O'Connor, Denise A McKeown. Determination of the Stability of 10 Novel Benzodiazepines and 3 Metabolites in Urine Using Lc - Ms/Ms. in 6th Annual Meeting of the United Kingdom and Ireland Association of Forensic Toxicologists (UKIAFT). 2016. Manchester.

142. P. Coassolo, C. Aubert,J.P. Cano, Plasma Determination of 3-Methylclonazepam by Capillary Gas Chromatography. Journal of Chromatography, 1985, 338, 347-355.

143. A.G. Artemenko, V.E. Kuz'min, E.N. Muratov, P.G. Polishchuk, I.Y. Borisyuk,N.Y. Golovenko, Influence of the Structure of Substituted Benzodiazepines on Their Pharmacokinetic Properties. Pharmaceutical Chemistry Journal, 2009, 43, 454-462.

144. S. Kar,K. Roy, Predictive Toxicity Modelling of Benzodiazepine Drugs Using Multiple in Silico Approaches: Descriptor-Based Qstr, Group-Based Qstr and 3d-Toxicophore Mapping. Molecular Simulation, 2015, 41, 345-355.

145. J.B. Hester, D.J. Duchamp,C.G. Chidester, A Synthetic Approach to New 1,4-Benzodiazepine Derivatives. Tetrahedron Letters, 1971, 12, 1609-1612.

146. K. Meguro,Y. Kuwada, Syntheses and Structures of 7-Chloro-2-Hydrazino-5-Phenyl-3h-1,4Benzodiazepines and Some Isomeric 1,4,5-Benzotriazocines. Tetrahedron Letters, 1970, 11, 4039-4042.

147. L.H. Sternbach, The Benzodiazepine Story. Journal of Medicinal Chemistry, 1979, 22, 1-7.

148. S.J. Childress,M.I. Gluckman, 1,4-Benzodiazepines. Journal of Pharmaceutical Sciences, 1964, 53, 577-590.

149. J.G. Whitwam, R. Amrein, Pharmacology of Flumazenil. Acta anaesthesiologica Scandinavica. Supplementum, 1995, 108, 3-14.

150. D.J. Maddalena,G.A.R. Johnston, Prediction of Receptor Properties and Binding Affinity of Ligands to Benzodiazepine/Gabaa Receptors Using Artificial Neural Networks Journal of Medicinal Chemistry, 1995, 38, 715-724.

151. N.W. Oilman,L.H. Sternbach, Quinazolines and 1,4-Benzodiazepines. Li. The Synthesis of the T-Butyl Analog of Diazepam. Journal of Heterocyclic Chemistry, 1971, 8, 297-300.

152. P.A. Borea, De Novo Analysis of Receptor Binding Affinity Data of Benzodiazepines. Arzneimittelforschung, 1983, 33, 1086-1088. 
153. E.K. W Haefely, M Gerecke, H Mohler, Recent Advances in the Molecular Pharmacology of Benzodiazepine Receptors and in the Structure-Activity Relationships of Their Agonists and Antagonists. Advanced Drug Research, 1985, 14, 165-322.

154. S.S. So,M. Karplus, Genetic Neural Networks for Quantitative Structure-Activity Relationships: Improvements and Application of Benzodiazepine Affinity for Benzodiazepine/Gabaa Receptors. Journal of Medicinal Chemistry, 1996, 39, 5246-5256.

155. The Drug Enforcement Administration (DEA), Mimic Alprazolam Tablet (Actually Containing Melatonin) Seized in New York. Microgram Bulletin, 2009, 42, 80.

156. The Guardian. [cited 2017 January]; Available from:

https://www.theguardian.com/society/2016/may/10/fentanyl-drug-overdoses-xanaxpainkillers.

157. Ecstasydata.org. [cited 2017 January]; Available from: https://www.ecstasydata.org/results.php?start=0\&search_field=all\&s=etizolam.

158. Y.K. Chong, M.M. Kaprawi,K.B. Chan, The Quantitation of Nimetazepam in Erimin-5 Tablets and Powders by Reverse-Phase Hplc Microgram Journal, 2004, 2, 27-33.

159. W.J.L. Lim, A.T.W. Yap, M. Mangudi, H.B. Koh, A.S.Y. Tang,K.B. Chan, Detection of Phenazepam in Illicitly Manufactured Erimin 5 Tablets. Drug Testing and Analysis, 2016 n/an/a.

160. B. Megarbane, S. Pirnay, S.W. Borron, H. Trout, C. Monier, P. Risède, G. Boschi,F.J. Baud, Flunitrazepam Does Not Alter Cerebral Distribution of Buprenorphine in the Rat. Toxicology Letters, 2005, 157, 211-219.

161. J. Broséus, N. Gentile,P. Esseiva, The Cutting of Cocaine and Heroin: A Critical Review. Forensic Science International, 2016, 262, 73-83.

162. M.L. Crichton, C.F. Shenton, G. Drummond, L.J. Beer, L.N. Seetohul,P.D. Maskell, Analysis of Phenazepam and 3-Hydroxyphenazepam in Post-Mortem Fluids and Tissues. Drug Testing and Analysis, 2015, 7, 926-936.

163. K. Ajir, M. Smith, K.M. Lin, J.C. Fleishaker, J.H. Chambers, D. Anderson, I. Nuccio, Y. Zheng,R.E. Poland, The Pharmacokinetics and Pharmacodynamics of Adinazolam: MultiEthnic Comparisons. Psychopharmacology, 1997, 129, 265-270.

164. J.C. Fleishaker, L.K. Hulst, T.C. Smith,H. Friedman, Clinical Pharmacology of Adinazolam and $\mathrm{N}$-Desmethyladinazolam Mesylate Following Single Intravenous Infusions of Each Compound in Health Volunteers. European Journal of Clinical Pharmacology, 1992, 42, 287-294.

165. J.C. Fleishaker,J.P. Phillips, Adinazolam Pharmacokinetics and Behavioral Effects Following Administration of 20-60 Mg Oral Doses of Its Mesylate Salt in Healthy Volunteers. Psychopharmacology, 1989, 99, 34-39.

166. J.C. Fleishaker,C.E. Wright, Pharmacokinetic and Pharmacodynamic Comparison of Immediate-Release and Sustained-Release Adinazolam Mesylate Tablets after Single-and Multiple-Dose Administration. Pharmaceutical Research, 1992, 9, 457-463.

167. K. Venkatakrishnan, K.E. Culm, B.L. Ehrenberg, J.S. Harmatz, K.E. Corbett, J.C. Fleishaker,D.J. Greenblatt, Kinetics and Dynamics of Intravenous Adinazolam, N-Desmethyl Adinazolam, and Alprazolam in Healthy Volunteers. Journal of Clinical Pharmacology, 2005, 45, 529-537.

168. Bluelight. [cited 2017 February]; Available from: http://www.bluelight.org/vb/threads/791664-Flunitrazolam.

169. G. Høiseth, S.S. Tuv,R. Karinen, Blood Concentrations of New Designer Benzodiazepines in Forensic Cases. Forensic Science International, 2016, 268, 35-38.

170. Bluelight. [cited 2017 January]; Available from: http://www.bluelight.org/vb/threads/775400-Cloniprazepam.

171. Reddit. [cited 2017 January]; Available from: https://www.reddit.com/r/researchchemicals/comments/5gciof/fonazepam_first_thoughts/

172. Flashback. [cited 2017 January]; Available from: https://www.flashback.org/t2650660. 
173. M. Lukasik-Glebocka, K. Sommerfeld, A. Tezyk, B. Zielinska-Psuja, P. Panienski,C. Zaba, Flubromazolam--a New Life-Threatening Designer Benzodiazepine. Clin Toxicol (Phila), 2016, 54, 66-68.

174. Mitsubishi Tanabe Pharma Corporation. [cited 2017 January]; Available from: https://medical.mt-pharma.co.jp/di/file/if/f_crm.pdf.

175. UK Chemical Research. [cited 2017 February]; Available from: https://www.ukchemicalresearch.org/Thread-meclonazepam.

176. S. El Balkhi, M. Chaslot, N. Picard, S. Dulaurent, M. Delage, O. Mathieu,F. Saint-Marcoux, Characterization and Identification of Eight Designer Benzodiazepine Metabolites by Incubation with Human Liver Microsomes and Analysis by a Triple Quadrupole Mass Spectrometer. International journal of legal medicine, 2017 http://dx.doi.org/10.1007/s00414-00017-01541-00416.

177. P. Kintz, C. Richeval, C. Jamey, A. Ameline, D. Allorge, J.M. Gaulier,J.S. Raul, Detection of the Designer Benzodiazepine Metizolam in Urine and Preliminary Data on Its Metabolism. Drug Testing and Analysis, 2016.

178. M. Katselou, I. Papoutsis, P. Nikolaou, C. Spiliopoulou,S. Athanaselis, Metabolites Replace the Parent Drug in the Drug Arena. The Cases of Fonazepam and Nifoxipam. Forensic Toxicology, 2017, 35, 1-10.

179. Pharmaceutical and Medical Devices Agency (PMDA) Japan. [cited 2017 January]; Available from: http://www.info.pmda.go.jp/downfiles/ph/PDF/400093_1124004F1042_2_07.pdf.

180. Japan Pharmaceutical Information Center (JAPIC). [cited 2017 January]; Available from: http://www.japic.or.jp/service/whats_new/japicnews/pdf/254.pdf.

181. Yakuzaishiharowa. [cited 2017 January]; Available from: http://yakuzaishiharowa.com/medical_pharmacy/bz-medicine.html.

182. UK Chemical Research. [cited 2017 February]; Available from: https://www.ukchemicalresearch.org/Thread-Nitrazolam.

183. E.C. Lomas,P.D. Maskell, Phenazepam: More Information Coming in from the Cold. Journal of Forensic and Legal Medicine, 2015, 36, 61-62.

184. B. Moosmann, P. Bisel, F. Franz, L.M. Huppertz,V. Auwarter, Characterization and in Vitro Phase I Microsomal Metabolism of Designer Benzodiazepines - an Update Comprising Adinazolam, Cloniprazepam, Fonazepam, 3-Hydroxyphenazepam, Metizolam and Nitrazolam. Journal of Mass Spectrometry, 2016, 51, 1080-1089.

185. G.W. Peng, Assay of Adinazolam in Plasma by Liquid Chromatography. Journal of Pharmaceutical Sciences, 1984, 73, 1173-1175.

186. S. Vikingsson, A. Wohlfarth, M. Andersson, H. Green, M. Roman, M. Josefsson, F.C. Kugelberg, R. Kronstrand, Identifying Metabolites of Meclonazepam by High-Resolution Mass Spectrometry Using Human Liver Microsomes, Hepatocytes, a Mouse Model, and Authentic Urine Samples. The AAPS journal, 2017.

187. C. Fracasso, S. Confalonieri, S. Garattini,S. Caccia, Single and Multiple Dose Pharmacokinetics of Etizolam in Healthy Subjects. European Journal of Clinical Pharmacology, 1991, 40, 181185.

188. T. Nakamae, T. Shinozuka, C. Sasaki, A. Ogamo, C. Murakami-Hashimoto, W. Irie, M. Terada, S. Nakamura, M. Furukawa,K. Kurihara, Case Report: Etizolam and Its Major Metabolites in Two Unnatural Death Cases. Forensic Science International, 2008, 182, e1-6.

189. K.C. Wang, M.C. Cheng, C.L. Hsieh, J.F. Hsu, J.D. Wu,C.K. Lee, Determination of Nimetazepam and 7-Aminonimetazepam in Human Urine by Using Liquid Chromatography-Tandem Mass Spectrometry. Forensic Science International, 2013, 224, 84-89.

190. A.L. Ékonomov, V.P. Zherdev, Method of Quantitative Gas-Chromatographic Determination of Phenazepam and Its Metabolite 3-Hydroxyphenazepam in Plasma. Pharmaceutical Chemistry Journal, 1980, 14, 579-582. 
191. I. Rasanen, I. Ojanperä,E. Vuori, Quantitative Screening for Benzodiazepines in Blood by DualColumn Gas Chromatography and Comparison of the Results with Urine Immunoassay. Journal of Analytical Toxicology, 2000, 24, 46-53.

192. A.D. Fraser, A.F. Isner,W. Bryan, Urinary Screening for Adinazolam and Its Major Metabolites by the Emit D.A.U. And Fpia Benzodiazepine Assays with Confirmation by Hplc. Journal of Analytical Toxicology, 1993, 17, 427-431.

193. M.R. Meyer, M.P. Bergstrand, A. Helander,O. Beck, Identification of Main Human Urinary Metabolites of the Designer Nitrobenzodiazepines Clonazolam, Meclonazepam, and Nifoxipam by Nano-Liquid Chromatography-High-Resolution Mass Spectrometry for Drug Testing Purposes. Analytical and Bioanalytical Chemistry, 2016, 408, 3571-3591.
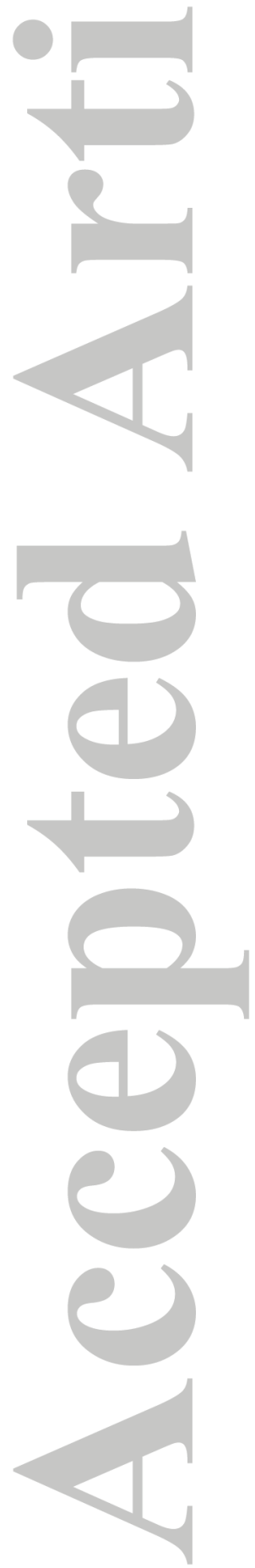

This article is protected by copyright. All rights reserved. 


\section{The Emergence of New Psychoactive Substance (NPS)}

\section{Benzodiazepines: A Review}

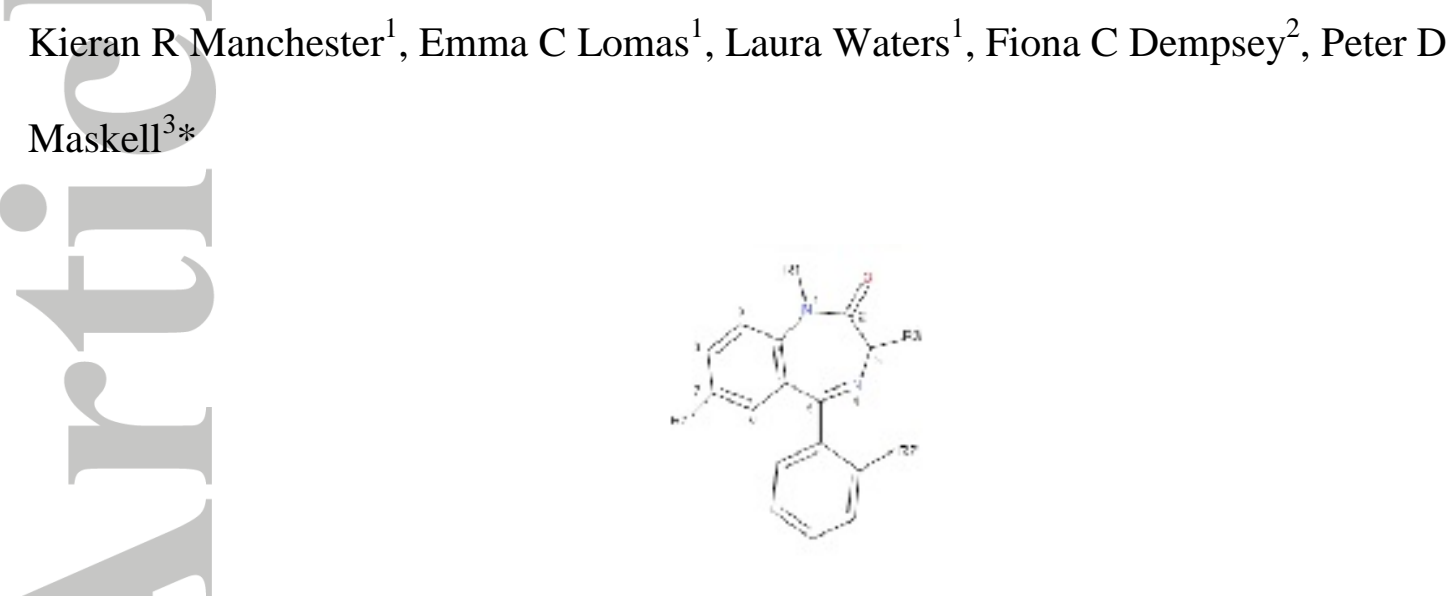

This paper critically reviews both the stage of knowledge of the emerging NPS-benzodiazepines and also the analytical methods that can be used to detect them.

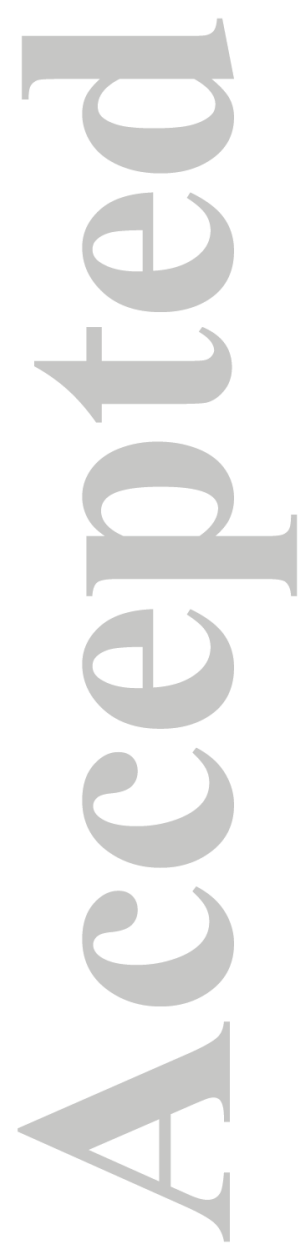

